\title{
Determinants of Capital Structure: Evidence from the UK
}

\author{
Sarah ALmuaither \\ King Saud University, Riyadh, Saudi Arabia \\ Mahmoud Marzouk \\ Menoufia University, Al Minufya, Egypt
}

\begin{abstract}
This study investigates the determinants of capital structure of UK firms by using the ordinary least squares (OLS) estimation with six independent variables including company size, profitability, tangibility, growth opportunities, tax, and volatility, as well as four industry classification dummy variables and with financial leverage as the dependent variable. The data set for the research includes all FTSE 100 companies in 2016. The findings reveal (i) a positive but insignificant relationship between company size and leverage; (ii) a negative but insignificant association between profitability and leverage; (iii) level of tangible assets and leverage are negatively related but such negative relationship is not significant; (iv) growth opportunities and leverage are negatively correlated and the negative relationship is highly statistically significant; (v) tax and leverage are positively related but the relationship is not statistically significant; and (vi) volatility and leverage are negatively related but the relationship is not statistically significant. The significant negative relationship between industry dummies and leverage is related to companies in the mining industry that did not use much debt to finance their business compared to those in other industries. Among five different capital structures, the pecking order theory indicates that companies prefer employing internal fund such as retained earnings or excess liquid assets to external finance investment opportunities, which seems to be suitable for UK companies. Static trade off theory which addresses the existence of optimal capital structures of firms affected by the trade-off between costs and benefits when using debt and equity is only applicable in particular cases in the UK. Dynamic trade off theory that argues that the appropriate financing choice typically relies on the financing margin that is estimated in the coming period, and market timing theory which demonstrates that stock price fluctuations in the market influence companies' capital structure, are not supported by the findings of this study.
\end{abstract}

Keywords: capital structure, company-specific characteristics, market factors, UK market influence

\section{Background and Research Rationale}

\section{Overview of the UK Context}

After the global financial crisis, the UK economy has turned into a steady growing phase. Particularly, in 2016, the country experienced a growth at the second fastest rate in the group of G7 economies. In spite of this

\footnotetext{
Acknowledgement: This research project was supported by a grant from the Research Centre for the Humanities Deanship of Scientific Research at King Saud University, and therefore, we would like to express our heartfelt gratitude for their support and encouragement.

Sarah ALmuaither, M.Sc., Lecturer in Accounting, College of Business Administration, King Saud University, Riyadh, Saudi Arabia.

Mahmoud Marzouk, Ph.D., Lecturer in Accounting and Auditing, Faculty of Commerce, Menoufia University, Al Minufya, Egypt.
} 
fact, the UK growth rate in recent years has not reached the level prior to the crisis (Figure 1). However, with regards to the economy size, the size of the UK economy reached its normal level before the crisis in the 2nd quarter of 2013 and since then, it has been gradually increasing (Figure 2). These changes may indicate the promising prospects of the country in coming years, others being equal.

\section{UK GDP growth}

\% change previous quarter
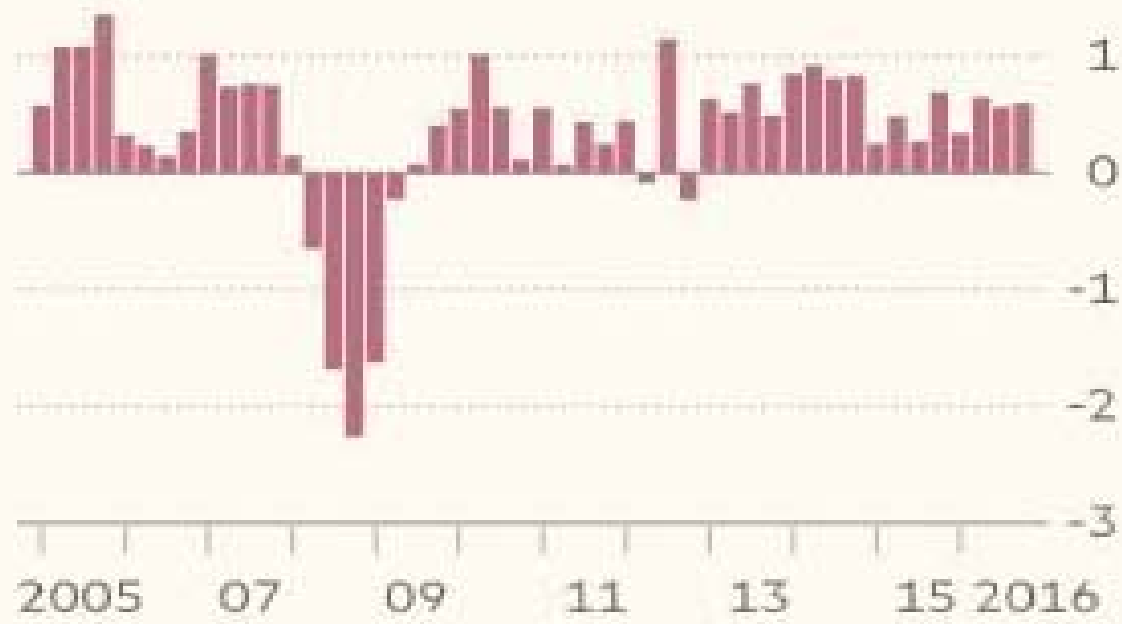

Figure 1. UK GDP growth (Source: Financial Times, 2017).

\section{The size of the UK economy}

\section{Ebn per quanter, 2011 prices}

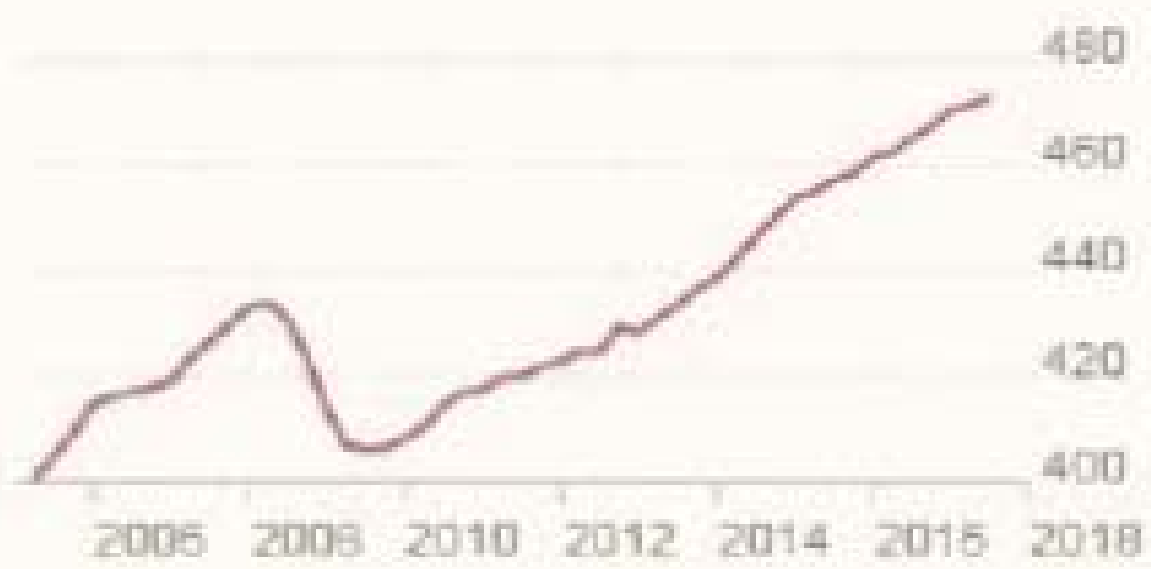

Figure 2. The size of the UK economy (Source: Financial Times, 2017). 
Nevertheless, since Britain has begun the negotiations to leave the EU (Brexit), it is forecasted that the fundamental change in the economic model would greatly affect the economy growth as well as business of organisations across the country. For example, firms operating in agriculture sector are among the ones which will experience greatest concerns, following by manufacturing sector, services, and financial services (Financial Times, 2017).

In terms of policy, the UK government "has continued with its strategy to deliver the most competitive corporate tax system in the G20, with the aim of encouraging greater investment to support productivity and growth, enabling UK based companies to compete successfully in global markets". Particularly, "the rate of corporation tax has been reduced from 28\% in 2010 to 20\% from April 2016, and from 2017 it will be reduced further to $19 \%$ then to $18 \%$ in 2020 " (HM Revenue and Customs, HM Treasury, 2016). Unfortunately, new interest tax deduction restriction was expected to be applied from 1 April 2017 in which "rules would increase compliance burden with highly geared groups significantly affected” (Walker, 2017, unpaginated).

In the UK, the base rate "dictates the interest level that at which banks and very large companies can borrow money". In turn, it presents the cue to banks and loan companies to compute "the interest levels they can charge to their customers" (Levene, 2015, p, 118). In the last decade, the UK government has retained a relatively low level of interest rate (the Bank of England cut the base rate from $0.5 \%$ to $0.25 \%$ in 2016) (BBC News, 2016), but it is anticipated that this trend is no longer in existence in years to come.

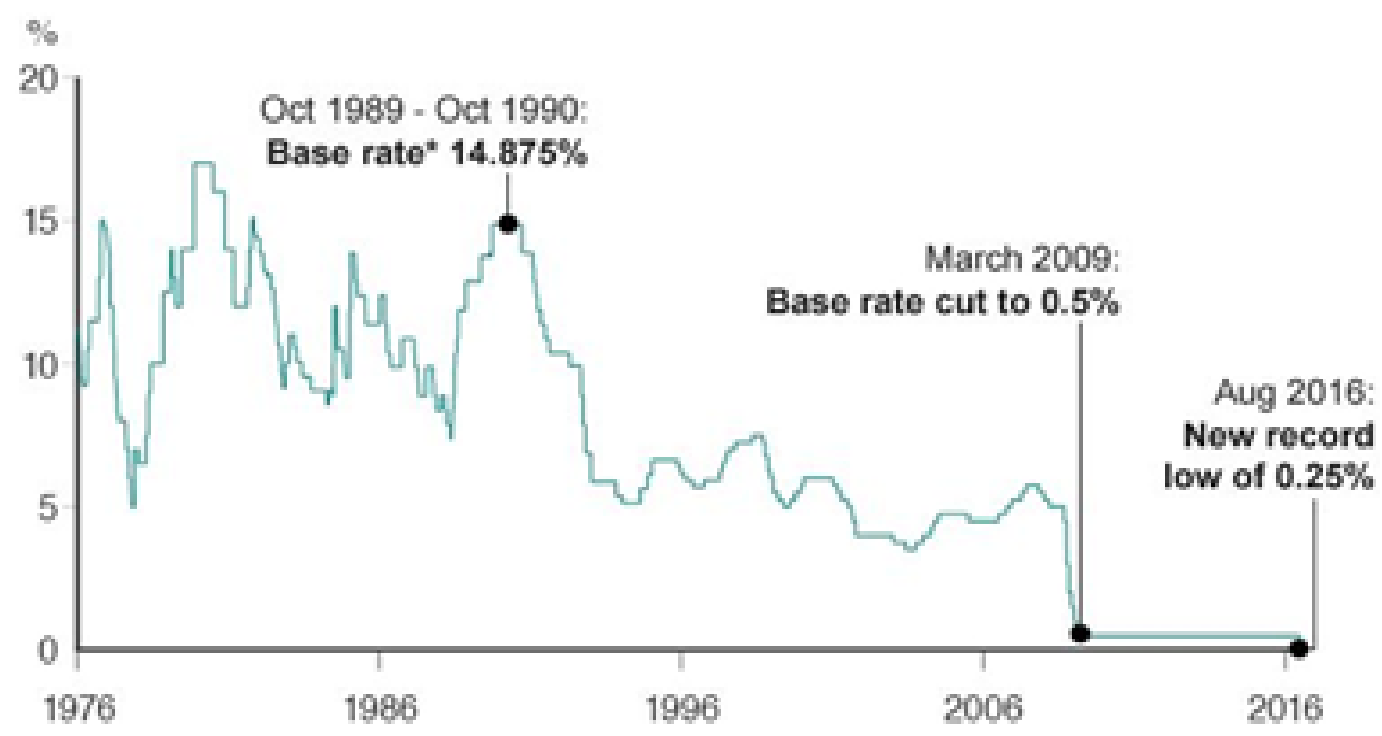

Figure 3. The UK base rate 1976-2016 (Source: BBC News, August 2016).

In terms of real interest rates for firms in Europe, the figure below shows that the UK real interest rates were used to be highest before June 2007 in Euro but reduced to lower level than that in the Spain, Germany, and France until 2009 and then increased to higher level than Germany and France. 


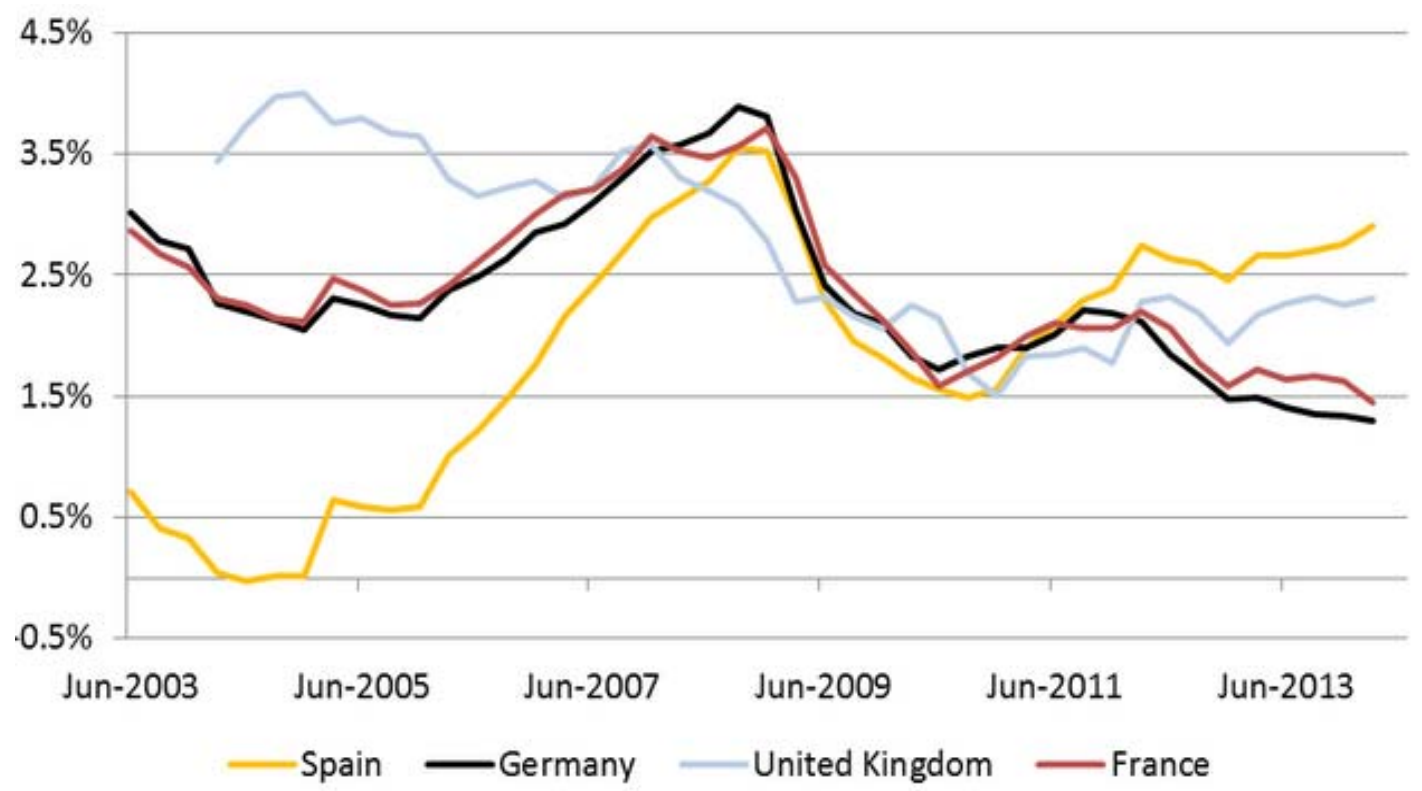

Figure 4. Real interest rates for firms in Europe (Source: Odendahl, 2014).

Although the latest similar data about real interest rates have not been published, in overall, the level of the UK real interest rates has been not increased dramatically since 2013, even relatively lowered since 2016. The review of the overall situation in the UK in the last 10 years shows that there would be certain changes in the country with regards to the macroeconomic conditions that may greatly affect all companies in the country.

\section{Overview of Capital Structure and Its Importance to Firms}

Generally, a company can be financed by varying levels of capital which is a mix of debts, equity, or other financial capital. According to Brounen, de Jong, and Koedijk (2006), under a technical perspective, capital structure is known as the thoughtful use of firms between different sources of capital, equity, and debt to finance their assets, daily operations, and strategic growth. Nevertheless, under a tactical perspective, capital structure affects all aspects of the business such as risk profile, cost of capital, return to shareholders, and relationship with fund providers etc.

In a developed economy like the UK, the capital structure decision is considered as a critical job of the financial manager, specifically in periods that the economy has been experiencing high uncertainty. In another word, debt policy holds a considerable role in overall business development strategy. This is because the primary purpose of finance managers is to maximise firm value, generating increasing wealth for shareholders. This means that obtaining perception about factors affecting the use of debt could be helpful for financial managers in planning borrowing capacity.

In addition, according to Brounen et al. (2006), because debt financing has the tax shield advantage but the risk of financial distress in case the level of debt in use goes over the optimal structure, it is important for financial managers to strategically combine this source of capital with equity financing in order to optimise value of the company. The framework of capital structure has been an area witnessing continuous academic disputes since the work of Modigliani and Miller in 1958; however, there has still been no theoretical model that can satisfy all parties (economists/researchers/practitioners). Firms around the world are continuously seeking the optimal capital structure but the methods that they are following are different from each other, 
depending on various factors. For examples, firms can base on the cost of capital indicator, profitability indicator, reference from industry average or risk profile, or even preference of the business owners etc.

The evolution of various capital structure theories can be summarised as following: Modigliani and Miller first developed a series of assumptions such as there are no taxes and transaction costs, no bankruptcy costs etc. and argued that in a perfect market, financial structure of company has no impact on its value, meaning that debt-to-equity ratio and company's total value are independent with each other. They further affirmed that the dividend pay-out that is chosen by a particular company has no influence on share price and firm's value. Then, trade off theory was in existence from the critical evaluation of the Modigliani and Miller theories that when there is an addition of corporate income tax, benefit of debt is created, shielding earnings from taxes. This theory therefore is about the decision of financing choice under the evaluation of benefits and costs associated with different leverage plans.

The trade off theory has two types, static and dynamic in which the first one states that optimal capital structures of firms are in existence that are affected by the trade-off between costs and benefits when using debt and equity while the other indicates that the appropriate financing choice typically relies on the financing margin that is estimated in the coming period. Pecking order theory has a totally different approach when it states that, in reality, companies prefer employing internal fund such as retained earnings or excess liquid assets to external to finance investment opportunities. Another theory, the market timing theory indicates that the issue of share is determined by the perception towards the stock price in the market, particularly, if stock is seen to be overvalued, more share will be issued but in case of undervalued, a buyback scheme will be implemented, and thus stock price fluctuations in the market influence companies' funding decision, capital structure.

Over the years, many researchers have reported their study results about behaviour of organisations in relation to the use of debt and the determinants of financing structure. In fact, a lot of difficulties in carrying out empirical tests on the subject are often mentioned, mostly due to the measurement of variables. Given all of the above, it can be seen that although determinants of capital structure are not a new topic but there are always challenges that a researcher need to be aware of in order to implement the empirical studies successfully. Most importantly, finding appropriate answers for the question of how to balance debt financing with other capital sources remain an interested area of researching about in finance field.

\section{Literature Review}

According to Brounen et al. (2006), capital structure, the decision in using debt and equity is a significant corporate policy affecting activities of any firm. In fact, although there has been an increasing amount of literature in finance analysing various aspects of capital structure since the first work of Modigliani and Miller in 1958, no single theory can fully justify the decision of companies reading capital structure.

Empirical papers have been implemented using data from countries all over the word to investigate determinants of capital structure and a vast amount of results are obtained. Thus, the understanding about what are considered by major previous studies is beneficial in terms of providing a full picture of the topic. Aiming at reviewing of the literature of capital structure's determinants, the section starts with the review of all major capital structure theories to obtain a theoretical perception about capital structure relevance. Then, the review will focus on papers that examine various factors affecting companies’ decision on capital structure. 


\section{Financial Leverage and Theories of Capital Structure}

According to Zietlow, Hankin, and Seidner (2007), debt, representing any agreement between a lender and a borrower: notes, certificates, bonds, debentures, mortgages and leases, is one of the significant items of a firm' capital structure that offers a medium for corporate financing since companies use debt in order to raise the capital they need for capital expenditure. The important feature of debt is that it is required to pay the original and interest to the fund provider in a given period of time. In financial structure of firms, debt includes short term and long term capital in which the first one represents the capital required for daily operations while the latter represents the funds needed for other longer term investment (more than one year) such as new development projects, construction, or new equipment purchases.

Shah and Hijazi (2004) emphasise that when using debt, if the obligations of payment are not fulfilled, credit rating will be negatively affected that makes companies much more difficult in approaching with more funds, increasing the possibility of confronting with financial failure. Along with the term "debt", financial leverage is often used to express the money (capital) that firms obtain from creditors (including leasing) in total capital they employed to finance their business. The terms "leverage" indicates that it could help enhance companies' strength in fund raising with a hope to increase the value. In practical, many advantages of financial leverage are recorded such as the increase of free cash follow, capturing economies of scale, changing credit rating (a proof of being good at handling risk), or increase value for shareholders. Nevertheless, the over-estimation of the benefit of financial leverage also leads to problems. Thus, it has been among great appealing areas of researching for many years in academics. In finance field, the theme of capital structure was initially introduced by Modigliani and Miller (1958) by capital structure irrelevance proposition and since then there has been a massive literature leading to the development of other relevant theories/models.

In order to develop their capital structure theory, Modigliani and Miller first developed a series of assumptions. Particularly, they assumed that there are no taxes and transaction costs, meaning that borrowing or lending without risk; there are no bankruptcy costs; debt issuance is for stock purchase and vice versus the issue of additional shares is for debt repay purpose; there are always perpetual and constant cash flows and earnings are only used to distribute to shareholders; and operating results of the firm can be predicted by all market participants.

Modigliani and Miller's original irrelevance theory of capital structure (irrelevance position) (1958) indicates that in a perfect market, financial structure of company has no impact on its value, meaning that debt-to-equity ratio and company's total value are independent with each other. The second irrelevance proposition (1961) affirms that the dividend pay-out that is chosen by a particular company has no influence on share price and firm's value, meaning that decision of choosing capital structure as well as dividend policy is irrelevant in perfect markets.

Although Modigliani and Miller theories fail in providing realistic descriptions with the existence of taxes, transaction costs, bankruptcy costs, agency conflicts etc., they have contributions in understanding reasons for the importance of financing. In the literature, the work of Modigliani and Miller has been the basis for many other theories of capital structure to develop aiming at justifying rationale behind the use of debt and equity that are trade-off theory and pecking-order theory (Drobetz \& Fix, 2005; Bas, Muradoglu, and Phylaktis, 2009).

Trade off theory relates to the decision of financing choice under the evaluation of benefits and costs associated with different leverage plans with an assumption that marginal costs and benefits are balanced when 
interior solution is obtained. The argument of this theory came out from the critical evaluation of the Modigliani and Miller theories that when there is an addition of corporate income tax, benefit of debt is created, shielding earnings from taxes.

There are two types of trade off theory, static and dynamic. The static one states that optimal capital structures of firms are affected by the trade-off between costs and benefits when using debt and equity. The main advantage of debt is tax shield but the prominent disadvantage is financial distress cost when the company over financed by debt that results in "a trade-off" between the tax advantage and the greater risk of financial distress. Nevertheless, the matter is much more than that because the use of debt and equity also entails agency costs.

According to Jensen and Meckling (1976) and Jensen (1986), agency costs originate from interest conflicts among various stakeholders of the company due to "ex post asymmetric information”. This indicates that a company's choice of capital structure is the trade-off between cost of financial distress (overuse debt) and agency cost against equity agency cost. Under this theory, firms that have capital structure which is different from the optimal one will tend to re-finance so that to make the leverage level close to the optimal ratio.

The dynamic trade-off theory indicates that the appropriate financing choice typically relies on the financing margin that is estimated in the coming period. Stiglitz (1973) is known as an important researcher greatly contributing to the development of modern dynamic trade-off theory through the investigation of taxation impact under public viewpoint (according to Goldstein \& Leland, 2001). Brennan and Schwartz (1984) investigate continuous time modes under the circumstances with taxes, bankruptcy costs, but without transaction costs. They report the same findings about immediate reaction from companies to unfavourable events by using less cost rebalancing methods and utilise large proportion of debt for tax savings benefit.

Goldstein and Leland (2001) study the situation of a particular company with low debt usage but having a chance to increase the leverage level and find that the leverage decision tends to be deferred to the next period. The finding implies that capital structure changes to reach optimal structure are tended to be implemented in long term rather than short term. Much of judgment on researching about dynamic trade-off models is relatively recent. Basically, the expectation in the next period to reach optimal level will affect the decision of current period that generates better understanding about role of earnings.

Pecking order theory which has a different approach in terms of optimal capital structure states that, in reality, companies prefer employing internal fund such as retained earnings or excess liquid assets to external to finance investment opportunities. In particular, the external source of finance will only be considered if there is a lack of internal funds and the choice of one or a number of external sources will be selected to make any additional cost to the lowest level. The rationale behind the pecking order theory is the interpretation of outside investors about companies' risk according to different financing options. Thus, under this theory, firms will give priority to internally generated funds, then low-risk debt funding and the last is equity financing.

The model of Myers and Majluf (1984) presents an analysis of investors' action of discounting share price of a company when there is conflict between issuing equity rather than using riskless debt. Thus, they suggest that in order to prevent such discount, managements only use equity funds when they have no other choice. That reveals a "pecking order" starting from internal funds to risky debt and equity.

This theory has implication in literature research. For example, Fama and French (2002) study the connection of market-to-book ratio and capital structure to analyse the function of market-to-book ratio in measuring investment opportunities. They find that high past market-to-book ratio is associated with high 
investment in the past and higher leverage. Both trade-off theory and pecking orders have received a lot of attention from researchers to investigate empirical evidence in terms of their usefulness in serving as a predictor of capital funding. The results are mixed but generally there are more supportive findings.

The market timing theory provides another approach to analyse capital structure choice of firms. The theory indicates that the issue of share is determined by the perception towards the stock price in the market. In particular, if stock is seen to be overvalued, more share will be issued but in case of undervalued, a buyback scheme will be implemented. As a result, stock price fluctuations in the market influence companies' funding decision, capital structure. Hence, there is no optimal capital structure.

Many researchers have investigated the meaning of this theory reality. For example, Graham and Harvey (2001) report that managers tend to consider the degree to which their company's share is overvalued or undervalued to be a significant factor, the determination of issuing common stock. Although this conclusion can confirm the assumption about managers' belief in being able to "time the market", it is fail to mention the situation of mispricing as well as the existence of asymmetric information. Baker and Wurgler (2002) show that capital structure of a company is dependent on equity market timing. They find that changes in debt proportion in total capital structure of a company are greatly positively linked to marketing timing measure which is a weighted average of external funds required in the past.

The review of capital structure theories is critically important. It can be seen that although there is no flawless theory in explaining companies' choice capital structure, these theories provide significant perspectives about what should and should not consider when analysing determinants of capital structure of various companies. Thus, the following section of this paper will be devoted to critically review major factors recommended by researchers worldwide affecting firms' capital structure.

\section{Determinants of Capital Structure}

Harris and Raviv (1991, p. 334) argue that "several studies shed light on the specific characteristics of firms and industries that determine leverage ratios" and according to these authors, generally there is an agreement about the association of leverage with "fixed assets, non-debt tax shields, growth opportunities, and firm size and decreases with volatility, advertising expenditures, research and development expenditures, bankruptcy probability, profitability and uniqueness of the product”. Hence, the review on determinants of capital structure will be categorised into major elements including company-specific characteristics and market factors as discussed below.

Capital structure and company size. Under the theoretical perspectives, there is ambiguity about the impact of size on leverage. Following the trade-off theory will lead to a prediction that larger companies may be featured as "more diversified, less risky and less prone to bankruptcy” (Acaravci, 2015, p. 161). There may be a preference of debt to equity financing for the purpose of control, resulting in a positive connection between size and leverage.

Rajan and Zingales argue that bigger organizations

tend to be more diversified and fail less often, so size (calculated as the logarithm of net sales) may be an inverse proxy for the probability of bankruptcy. If so, size should have a positive impact on the supply debt. (1995, p. 1451)

Nevertheless, size may convey other information to outside investors that could influence their choice of equity over debt. In addition to the natural logarithm of net sales, in the literature size also can be measured by average value of total assets, total assets at book value, and the market value of the firm. This means the use of different 
measurement may lead to different findings. Moreover, the level of statistical significance reported from the empirical tests for the relationship of such variables is often weak.

Graham, Lemmon, and Schallheim (1998) propose an argument that large firms experience less risk of bankruptcies, so that they have better approaches to various funding sources in the market. Moreover, Sayilgan, Karabacak, and Kucukkocaoglu (2006) claim that large firms may receive protection from the government, meaning better changes to borrow money in the market. Investigating this relationship in small and medium firms, Lopez-Garcia and Sogorb-Mira (2008) find a positive outcome and bankruptcy risk is inversely related with size. Jin (2012) also reports positive correlation between two variables, size of firms and their financial leverage.

Approaching the issue under pecking order view, Harris and Raviv (1991) support the positive relation due to a fact that large firms (having more tangible assets) are able to offer market participants with more information resulting better opportunities to meet new funding providers' needs. In addition, starting with pecking order theory, Gaud, Jani, Hoesli, and Sarig (2005) affirm that there is a positive impact of size on the indebtedness in case companies use external sources of funding but there is a negative effect if using method of issuing additional share to raise capital.

Capital structure and growth opportunities of companies. From the trade-off model perspectives, companies having more investment opportunities tend to rely on less debt due to greater motivations in being under-invested that may lead to agency conflicts. Similarly, pecking order theory also indicates a similar meaning.

There are empirical researches support the theoretical forecast of such negative connection; however, there are several opposite conclusions. Myers (1977) notes that companies experiencing good growth should be financed by more equity. This is because a greater leveraged firm could be more likely to lose profitable investment chances. Taking into account the market-to-book ratio as a proxy for growth opportunities, Rajan and Zingales (1995) note that companies with larger market-to-book ratio may witness higher financial distress costs which, in turn, leads to a negative relationship with leverage. Fama and French (2002) present the same argument in terms of the negative correlation between growth opportunities and leverage that companies with high investment opportunities do not consider debt as a priority when seeking fund to finance such investment plans.

Based on the argument from the theory of agency costs, Jensen (1986) shows that the more growth opportunities presented to companies, the more the indebtedness could be. This is to reduce the agency costs between managers and shareholders since the use of debt financing could help discipline managers. Song (2005) considers that high growth opportunities will require more amount of capital that creates motivations for managers to seek external funding source bringing better earnings to creditors.

Capital structure and profitability of companies. Profitability is an important indicator of company's health; however, its influence on leverage has no consistent theoretical forecast. The trade-off theory should reveal that more profitable companies experience greater leverage as there are more incomes to take tax advantage. Following this viewpoint, Bauer (2004) suggests that more profitable organisations should utilise more debt because this could help discipline managers through the avoidance of investing on projects lack of efficiency by paying out cash. The empirical result on positive linkage between profitability and leverage is also reported by Fattouh, Harris, and Scaramozzino (2002). 
Nevertheless, from the view of pecking-order theory, companies wish to use internal funding first, then external one. Thus, more money-making companies witness not much need for external source of funding, meaning lower leverage. Typical researchers focus on analysing a negative connection between profitability and leverage include Myers and Majluf (1984), Jensen et al. (1992), Bathala et al. (1994), Rajan and Zingales (1995), De Miguel and Pindado (2001), and Schargrodsky (2002) etc. (Acaravci, 2015, p. 161).

Capital structure and tangibility of companies. Most capital structure theories claim that the categories of assets possessed by companies in certain circumstances influence their capital structure decision. The trade-off theory foresees that when using as collateral, tangible assets could help reduce risk for creditor, thus tangibility has an important role in helping firms increase leverage. In addition, tangible assets could support in lowering financial distress cost. Notably, agency theory presents a negative correlation between tangibility of assets and leverage.

Booth, Aivazian, Demirguc-Kunt, and Maksimovic (2001) mention that there is a positive connection between tangibility and indebtedness since the more tangible assets that firms own in terms of value and number, the better they can secure debt, helping avoid the leakage of future profits information. Titman and Wessels (1988) focus on analysing the helpfulness of tangible versus intangible assets relating to the ability of firms in boosting leverage based on the collateral value.

Capital structure and tax. Theoretically, tax has a determining role in companies' capital structure choice. According to the trade-off theory, higher tax rate should lead to the increasing use of debt since there will be higher earnings to shield from taxes. Gertler and Hubbard (1989) argued that there could be an encouragement to corporations generated from the tax system in order to "absorb more business cycle risk than they would otherwise". This is because of the generation of "a relative subsidy to debt finance" and debt renegotiation to retain debt financing in the capital structure. Faccio and Xu (2015) studied nearly 500s shifts in statutory corporate and personal income tax rates in OECD countries "as natural experiments" to investigate the impact of taxes and capital structure. Based on their data analysis, they reported that both taxes were significant determinants of capital structure.

Nevertheless, not all empirical studies support the positive impact of taxes on financial leverage. For example, Fama and French (1998) state that there are not net tax benefits of debt. Dwenger and Steiner (2009) collected data on the basis of a pseudo-panel for the period from 1998 to 2001 to investigate how effective profit taxation influences the financial leverage of firms in Germany in which financial leverage's measurement is the ratio of long term debt to total capital. They find that there is no endogenous change of financial structure when effective profit taxation slightly changes; however, interestingly, they find that when effective tax rate increases significantly, the impact on leverage is considerable. In particular, an increase by $10 \%$ of effective tax rate could lead to an increase by $5 \%$ in the financial leverage.

Capital structure and volatility. Volatility is perceived to be risk's proxy of a company, thus there is a prediction about the negative relationship between volatility and leverage. Nonetheless, not all empirical findings are supportive of this argument. Normally, volatility is measured by standard deviation of returns on assets. For example, Huang and Song (2002, p. 2) conclude that the systematic risk of equity reduces when there is an increase in variance of firms' assets value meaning that "business risk is expected to be positively related to leverage".

Halov, Heider, and Kose (2009) argue that volatility of risk could be an important element in justifying firms' capital structure decision. They run a regression model for data collected from CRSP-Compustat (CCM) 
database and find the significantly negative relationship leverage and volatility of risk and the relationship is stronger with companies having no credit rating.

Capital structure and business sector. A statistically significant correlation between sector group and leverage has been reported since each industry has its own characteristics affecting capital structure of firms operating in it. Harris and Raviv (1991, p. 333) implement a survey of empirical studies and find that "Drugs, Instruments, Electronics, and Food have consistently low leverage while Paper, Textile Mill Products, Steel, Airlines, and Cement have consistently large leverage”. Titman (1984) and Titman and Wessels (1988) declare that manufacturer of machines and equipment should employ less debt in capital structure as using too much debt could influence their sustainability. Pacheco and Tavares (2015) pay attention of SMEs in footwear sector and their findings show that firms in this sector should follow pecking order when determining changes in their capital structure. Their database bases on the data from footwear companies listed in the EU.

Capital structure and company age. There is an argument that younger and small organizations are more reliant on debt financing since their level of retained earnings is not large enough to sufficiently meet their capital investment demand (Myers \& Majluf, 1984). This follows the perspective of pecking order theory that companies always seek to enhance their capacity in retaining internal resources first and then move to other options to obtain capital for investment opportunities.

From the view of trade-off theory, more established (older) companies witness better chances in having good investment projects; positive linkage therefore is predicted. Abor and Biekpe (2009) show that age is an important element in approaching finance, because the more mature the company is, the more guarantees they can offer creditors in case they are fail to honour obligations. Interestingly, some researchers such as Ramalho and Silva (2013) find a negative connection between indebtedness and the firm's age. They propose the analysis that older companies can create sufficient internal resources, so that they can be less relying on leverage as younger ones.

Capital structure and liquidity. There is a mixture outcome in terms of the effect of liquidity on capital structure choice of firms. Ozkan (2001) find that liquidity and leverage are negatively related since when companies use more debt it will lead to greater liabilities but lesser remaining current assets. Furthermore, agency theory indicates that outside fund providers tend to introduce limit on fund available to companies that are understood as having high agency costs of liquidity, according to Myers and Rajan (1998). Sbeti and Moosa (2012) argue that if companies base on pecking order theory to make decision about capital structure, there will be a negative connection between liquidity and financial leverage. However, others mention that because companies with greater liquidity ratios could experience a higher debt in capital structure to better meet obligations in short term, a positive relationship between debt ratios and companies' liquidity should be in existence.

Capital structure and regional and local effects. There is another external factor affecting firms' choice of capital structure that is outside environment in which firms conduct their business. Rajan and Zingales (1995) study the decisions related to capital structure of companies located in G7 (developed countries) and find that in general companies in these areas it retains similar level of leverage and there are certain common elements affecting their capital structure choice apart from country of origin. Giannetti (2003, p. 210) bases on data on a number of European countries affirms that financial development and investor protection are important drivers of leverage: "firms that invest more intensively in intangible assets are penalised less for lack of collateral in countries with good creditor protection”. De Jong, Kabir, and Nguyen (2008), analyse the database including 
different-sized firms from 42 countries in 1997-2001 frame and emphasise that there is a difference in specific determinants of indebtedness across countries and that it is important to consider country factor in capital structure decisions.

More attention in capital structure filed has been paid to developed countries. However, in recent years, there have been many works focusing on the matter in developing countries to investigate if there is any particular difference in the factors influencing companies' capital structure in such countries. For instance, Vo (2017) implements a research on Vietnam stock market—an emerging market and finds that because of unique legal, cultural, and institutional features, determinants of capital structure of companies in this particular country are different from other developed countries. Notably, in an emerging market as Vietnam, long term and short term determinants of capital structure are not the same. Vo states that "there is little work done on examining capital structure in these emerging countries" and "the forces behind capital structure decision in emerging markets are still an open question for investigation” (2017, p. 105).

The review of 10 groups of determinants as presented reveals that most of the studies seeking to point out determinants of capital structure are based on a quantitative analysis approach. In particular, the authors gather numerical data in a certain time frame create hypotheses and apply econometrics testing models—such as the multiple regression model - to analyse the data, discovering relationship between variables. In addition, researchers often study a group of factors affecting capital decision of companies rather than a single factor. Also, each author will create a set of assumptions for his research before running testing models. Thus, different assumptions may lead to different outcomes even if the same approach is followed.

\section{Research Methodology}

According to Bryman and Bell (2011), employing numerical data to gain information is the major characteristics of a quantitative research and thus, the quantitative research is appropriate with studies that focus on analysing causal relationship between variables. However, the employment of non-numerical data of a qualitative research is to discover deeper insights through collecting people's opinions/behaviours.

Bryman and Bell (2011) note three aspects, including principal orientation of the role of theory in relation to research, epistemological orientation, and ontological orientation for the fundamental differences of these two strategies as shown below.

Table 1

Reserch Philosophy and Approaches

\begin{tabular}{|l|l|l|}
\hline & Quantitative & Qualitative \\
\hline $\begin{array}{l}\text { Principal orientation to the role of } \\
\text { theory in relation to research }\end{array}$ & Deductive, testing of theory & Inductive, generation of theory \\
\hline Epistemological orientation & Natural science model, in particular positivism & Interpretivism \\
\hline Ontological orientation & Objectivism & Constructionism \\
\hline
\end{tabular}

Notes. Source: Bryman \& Bell, 2011, p. 27.

In this research, because the aim is to discover the major factors affecting capital structure of companies in the UK, the quantitative method is in use. This research strategy requires us to apply relevant model and select suitable data. The following section presents these two contents in detail.

\section{Model Approach and Data Collection}

In order to test relationship between variables, multiple regression analysis (ordinary least squares-OLS 
estimation) is utilised. This is a statistical method of "predictive modelling technique" that allows us to examine the causal relationship between variables (including a dependent variable and one or more than one independent variables—predictor):

$$
y_{i}=\beta_{0}+x_{i} * \beta_{1}+\varepsilon_{i}(\mathrm{i}=1, \ldots, \mathrm{n})
$$

In equation (1):

$\varepsilon_{i}$ is the error term in predicting the value of dependent variable $y_{i}$.

$\beta_{i}$ is the coefficient of the independent $x_{i} . \beta_{i}$ can be a negative or positive value or equals zero (meaning there is no effect on the independent variable). The sign of beta indicates a negative or positive relation between the independent variable and the predictor.

$\beta_{0}$ is the inception of the regression, meaning the value of $\mathrm{y}$ when all $\mathrm{x}$ equal zero.

The outcomes from running a regression model can reveal (i) the significance of the relationship between dependent variable and independent variables, and (ii) the strength of the effect of each independent variable on the dependent variable.

Although there are many elements that can have impact on capital structure decision of a particular company, this research only pays attention to six factors that are used in the regression model as predictors, including: size (SIZE), profitability (ROA), tangibility (TANG), growth opportunities (PB), tax (TAX), and volatility (VOLTY).

This decision is based on the knowledge gain from literature review as well as the feasibility in data collection, meaning that there are some good explanatory factors but it is challenging in successfully the data needed. For example, the study does not take into account the age of the company as an explanatory variable because over the years there have been so many merger and acquisition activities changing business structure significantly that makes "the age" less relevant. The testing model in this research therefore is as the below:

$$
L T=\alpha+\operatorname{SIZE} * \beta_{1}+R O A * \beta_{2}+T A N G * \beta_{3}+P B * \beta_{4}+T A X * \beta_{5}+V O L T Y * \beta_{6}+\varepsilon
$$

The conclusions about the effect of these factors on capital structure in literature are various. The Table 2 below presents the summary of theoretical and empirical findings for the impact of each factor on the capital structure of companies in different markets.

Table 2

Summary of Theoretical and Empirical Findings

\begin{tabular}{lllll}
\hline & Theoretical prediction & G7 countries & Developed countries & Developing countries \\
\hline Size & $+/-$ & $+(-)^{*}$ & $-(+)^{*}$ & $+(-)^{*}$ \\
Profitability & $+/-$ & $-(+)^{*}$ & $-(+)^{*}$ & - \\
Tangibility & + & + & + & $-(+)^{*}$ \\
Growth opportunities & - & - & $-(+)$ & ${ }^{*}(+)^{-}$ \\
Tax & + & & & $-(+)^{*}$ \\
Volatility & $+/-$ & & $-(+)$ & $-(+)^{*}$ \\
\hline
\end{tabular}

Notes. ${ }^{*}$ Bracket means less often.

This research plans to test the model as shown on Equation 2 and compare with the previous results as summarised on Table 2. In addition, as reviewed, some researchers suggest that industry classification is also an important factor affecting decision of companies in determining capital structure, meaning different business sectors should have different leverage ratios. Thus, developing Model 2, the research also examines the following model, Model 3 with a dummy variable which is industry classification, particularly four groups of 
industries—production and distribution of electricity, gas, and water; retail industry; manufacturing industry; and mining of raw materials.

According to Skrivanek (2009), a dummy variable (indicator variable) is "an artificial variable created to represent an attribute with two or more distinct categories/levels" and "assign the numbers ' 0 ' and ' 1 ' to indicate membership in any mutually exclusive and exhaustive category”. Normally, regression method treats all explanatory variables as numerical; however, when we want to "include an attribute or nominal scale variable" (type of brands, type of products etc.), dummy variables are generated.

$$
\begin{aligned}
L T=\alpha+S I Z E * \beta_{1}+R O A * \beta_{2}+ & T A N G * \beta_{3}+P B * \beta_{4}+T A X * \beta_{5}+V O L T Y * \beta_{6}+D_{1}+ \\
& D_{2}+D_{3}+\varepsilon
\end{aligned}
$$

in which: $\mathrm{D}_{\mathrm{i}}$ is dummy variables:

\begin{tabular}{|l|l|}
\hline D1 (Industry dummy) & $=1$ if the company is in production and distribution of electricity, gas, and water; and = 0 for otherwise. \\
\hline D2 (Industry dummy) & $=1$ if the company is in retail industry; and = 0 for otherwise. \\
\hline D2 (Industry dummy) & $=1$ if the company is in manufacturing industry; and = 0 for otherwise. \\
\hline D4 (Industry dummy) & $=1$ if the company is in mining of raw materials; and = 0 for otherwise. \\
\hline
\end{tabular}

In addition, after running all multiple regression models, an examination of leverage level of all companies classified into industries is implemented. The combination of results from this examination with those from regression models would help generate better interpretation of findings.

The data set in this research include all listed companies in FTSE 100 and the year of financial accounting is 2016. As mentioned, the reason for choosing this particular stock index is because it includes listed firms with largest capitalisation in London Stock Exchange. For each company, the raw data are downloaded from Bloomberg and then the measurement of all seven variables as shown on Table 3 is worked on an Excel spreadsheet. The statistical program used to run regression is Eviews.

The measurement of each variable in the regression model is important as it determines the data input used for running the regression analysis. Although there can be more than one ways to measure the observed variables, the knowledge gained from literature review helps select the most relevant measurement for all variables. As a result, the Table 3 below presents the measurement of each predictor and the dependent variable of Models 2 and 3.

Table 3

Variables' Measurement

\begin{tabular}{|l|l|}
\hline Variables & Measurement \\
\hline Size (SIZE) & Sales \\
\hline Profitability (ROA) & EBIT/total assets \\
\hline Tangibility (TANG) & Tangible assets/total assets \\
\hline Growth opportunities (PB) & P/B ratio \\
\hline Tax (TAX) & (Earnings before tax-earnings after tax)/earnings before tax \\
\hline Volatility (VOLTY) & Standard deviation of ROA \\
\hline Capital structure (Leverage) (LT) & Total debt (total debt + book value of equity) \\
\hline
\end{tabular}

\section{Data Description}

The data set in my research include 101 observations (100 companies but there is 02 stock RDSA-Royal Dutch Shell Plc. A and RDSB-Royal Dutch Shell Plc. A belongs to 01 group). Full dataset is presented in Appendix A. There is no missing data for all companies in which there are 11 financial values collected for 
each company for calculating all variables as shown on Table 3.

This research studies a sample of individuals (all companies listed in FTSE 100 index) that are randomly selected from a population (all companies in the UK) with a goal of studying the sample and then applying the results to all the individuals constituting the population. Thus, it is important to understand main characteristics of the sample as well as to examine if there is any uncommon feature needed to solve by modifying the data. The following indicators are studied in the sample of collected data.

Table 4

Statistical Definitions

\begin{tabular}{|l|l|}
\hline Mean & The average, representing the central value of a series of numbers \\
\hline Median & The middle value of a data set, separating the data from the higher half and lower half \\
\hline Maximum & The largest value \\
\hline Minimum & The lowest value \\
\hline Std. Dev. & The standard deviation indicates the dispersion of the data set from its mean \\
\hline Skewness & To assess the probability distribution's asymmetry \\
\hline Kurtosis & To assess the probability distribution's tailedness \\
\hline Observations & Number of data points \\
\hline
\end{tabular}

The detailed results of data description for these main indicators are summarised in the Table 5 below.

Table 5

Data Description

\begin{tabular}{|c|c|c|c|c|c|c|c|c|c|c|c|}
\hline & D1 & D2 & D3 & D4 & PB & ROA & SIZE & TANG & TAX & VOLTY & LT \\
\hline Mean & 0.089109 & 0.069307 & 0.158416 & 0.069307 & 6.308981 & 0.069384 & 20724671 & 0.771085 & 0.321390 & 0.035962 & 0.639787 \\
\hline Median & 0.000000 & 0.000000 & 0.000000 & 0.000000 & 4.100000 & 0.061747 & 8159000. & 0.890424 & 0.217517 & 0.023648 & 0.655311 \\
\hline Maximum & 1.000000 & 1.000000 & 1.000000 & 1.000000 & 56.07000 & 0.358699 & $2.34 \mathrm{E}+08$ & 1.000000 & 5.377622 & 0.209575 & 1.259310 \\
\hline Minimum & 0.000000 & 0.000000 & 0.000000 & 0.000000 & -4.510000 & -0.248063 & -10744.00 & 0.000000 & -1.074946 & 8.50E-05 & 0.071518 \\
\hline Std. Dev. & 0.286322 & 0.255242 & 0.366952 & 0.255242 & 7.719605 & 0.072027 & 41186037 & 0.256666 & 0.638438 & 0.039911 & 0.223540 \\
\hline Skewness & 2.884449 & 3.391613 & 1.871025 & 3.391613 & 3.403406 & 0.145102 & 3.931886 & -1.095109 & 5.573319 & 2.023216 & -0.349407 \\
\hline Kurtosis & 9.320048 & 12.50304 & 4.500735 & 12.50304 & 19.56221 & 7.867929 & 18.87631 & 3.258422 & 42.16032 & 7.318781 & 2.927864 \\
\hline Observations & 101 & 101 & 101 & 101 & 101 & 101 & 101 & 101 & 101 & 101 & 101 \\
\hline
\end{tabular}

Based on the outcome presented on this table, there is no particular consideration leading to a modification of the collected sample. With regards to leverage, in average all listed firm in the FTSE100 employed 63.97\% of debt financing in their total capital. Notably, InterContinental Hotels Group Plc. had more than $100 \%$ of total capital (125.93\%) while Randgold Resources, a company in mining sector, utilised only less than 8\% of their total capital with debt in 2016. With a negative skewness, the set of statistical data of LT variable had left skewed distribution (the mean is on the left of the central point of the data set). Among these variables, only capital structure (LT) and tangibility (TANG) were left skewed; all others were right skewed distribution (the mean is on the right of the central point of the data set).

Regarding the Kurtosis, only capital structure (LT) had Kurtosis that is smaller than three, indicating a platykurtic distribution, producing less extreme outliers than that of normal distribution. All other distributions were with Kurtosis greater than three. In 2016, FTSE 100 companies achieved 6.9384\% of ROA in average in which the highest ROA level is $35.869 \%$ and the lowest is $-24.80 \%$, a very wide range in profitability. 
Growth opportunities (P/B ratio) of FTST 100 companies were greatly different from each other in the range from a negative value, -4.51 to very high value 56.07 with the average of 6.3 in 2016. Tangibility has the highest level of 1.0 because it is measured by the ratio "Tangible Assets/Total Assets". In 2016, the average tangibility ration of UK listed firms in FTST 100 was 0.771 in which there were 18 companies having $100 \%$ total assets classified as tangible assets and one company had no tangible assets, Schroders Plc. (SDR).

Size, measured by sales, of the FTSE 100 companies in 2016 also experienced a considerable gap from negative values to millions pound sterling with the average sales of 20,724,671. The ratio of tax (earnings before tax —earnings after tax)/earnings before tax) and volatility (standard deviation of ROA) of FTSE 100 did not experience a big gap in 2016 with the average of 0.321 and 0.0359 respectively. Regarding the standard deviation, among observed variables, the data set of SIZE and PB experienced more dispersion from their means in comparison to others.

\section{Research Reliability, Validity, and Ethical Considerations}

It is a shortcoming if there is no mention about the reliability, validity, and ethical considerations of the research as it determines to what extent the report contents can be reliable and acceptable.

Research reliability and validity depends on the correctness of the data set as any errors in data collecting and processing would result in diversion in final outcomes. Being well aware of this, I was very careful in the all the work related to data collection, from downloading raw data to process with raw data in Excel spreadsheet and applying data set in Eviews. In addition, during the process working on the data collection and analysis, I found no errors on raw data that requires any amendment or alteration which may affect the correctness of model running results.

The selection of modelling method-regression analysis appears logical enough as it is backed up by a thoughtful review from previous works rather than being in rush to pick up a random method. The measurement of each variable was also carefully determined based on the knowledge gained from literature review.

\section{Data Analysis and Findings}

This section presents the outcomes from running multiple regression model and the comparison of average financial leverage as explained in previous section, interpretation of the results, and the comparison of findings with previous empirical outcomes. The clear structure of this section is to ensure the coherence of the discussion and analysis, avoiding confusions to readers.

\section{Regression Results}

The first section is the presentation of the regression results. The table below summarises all the variables included in the three regression testing models. The OLS estimation method could help determine the impact of each independent variable on the dependent variable — financial leverage based on the sign and obsolete value of the coefficient. 
Table 6

Determinants of Capital Structure

\begin{tabular}{|l|l|}
\hline Variables & Measurement \\
\hline Size (SIZE) & Sales \\
\hline Profitability (ROA) & EBIT/total assets \\
\hline Tangibility (TANG) & Tangible assets/total assets \\
\hline Growth opportunities (PB) & P/B ratio \\
\hline Tax (TAX) & (Earnings before tax - earnings after tax)/earnings before tax \\
\hline Volatility (VOLTY) & Standard deviation of ROA \\
\hline Capital structure (Leverage) (LT) & Total debt (total debt + book value of equity) \\
\hline D1 (Industry dummy) & $=1$ if the company is in production and distribution of electricity, gas, and water; = 0 otherwise \\
\hline D2 (Industry dummy) & $=1$ if the company is in retail industry; = 0 otherwise \\
\hline D2 (Industry dummy) & $=1$ if the company is in manufacturing industry; = 0 otherwise \\
\hline D4 (Industry dummy) & $=1$ if the company is in mining of raw materials; = 0 otherwise \\
\hline
\end{tabular}

First of all, by using OLS estimation, the model including five explanatory variables (SIZE, ROA, TANG, $\mathrm{PB}$, and TAX) was tested. The detailed results are as shown on Appendix B in which the R-squared is $26.45 \%$. Because the R-squared of the testing model indicates how many changes in the dependent variable (leverage) that all explanatory variables can account for, meaning the explanatory power of the model, it is worth finding for the regression model resulting higher R-squared, others being equal. Consequently, one more independent added in the model — volatility (VOLTY) in order to investigate determinants of capital structure. As seen on the Appendix C, the new model results in a higher R-squared, 29.03\%-implying that $29.03 \%$ changes in leverage of companies in the sample can be explained by six independent variables. Therefore, dummy variables are included to see if the final model can provide better R-squared. The Table 7 below illustrates the results of the last test (the full testing results are presented in Appendix D).

Table 7

OLS Estimation Results

\begin{tabular}{ll}
\hline Variable & Coefficient \\
\hline C & 0.803622 \\
SIZE & $(9.329556)^{* *}$ \\
& $5.54 \mathrm{E}-10$ \\
ROA & $(0.927336)$ \\
& -0.205483 \\
TANG & $(-0.702452)$ \\
TAX & -0.057879 \\
& $(-0.667778)$ \\
VOLTY & 0.052724 \\
& $(1.536217)$ \\
PB & -0.831098 \\
& $(-1.604116)$ \\
D1 & -0.013707 \\
& $(-5.256604)^{* * *}$ \\
D2 & 0.026596 \\
& $(0.316774)$ \\
D3 & -0.046922 \\
& $(-0.580755)$ \\
D4 & -0.018865 \\
R-squared & $(-0.33445)$ \\
\hline
\end{tabular}

Notes. $* * *=1 \%, * *=5 \%, *=10 \%$ level of significance. 
As seen, the R-squared of the testing model is $33.2098 \%$, meaning that all explanatory variables can account for almost one fifth of changes in capital structure of firms in the sample. This indicates that explanatory power of the model (R-square) is $33.2098 \%$, and it is worthy testing such the model as when adding dummy variables, the explanatory power of the model slightly increases.

Empirical findings predict that the relationship between size and leverage is ambiguous and mainly presents a positive relation. Our results also support this conclusion. However, SIZE is not statistically significant at the $1 \%$ level in this model. Therefore, the findings of SIZE are considered as key ratio to access the probability of bankruptcy is not supported by the results of data analysis.

Secondly, majority of empirical studies state that there is a negative relationship between profitability (EBIT/TA) and leverage. In fact, my data analysis results provide the same outcome, as coefficient equals -0.205483 . However, the relationship between ROA and leverage is not statistically significant at $10 \%$ level in this model.

According to the theoretical point of view, a positive relationship is expected between leverage and the level of tangible assets. To explain this, tangible assets are more liquid than intangible assets; therefore it has higher market value in secondary market. In case of bankruptcy, these could be quickly and easily liquidated, therefore, debtors are willing to lend more for companies with higher intangible assets. However, according to the results of this study, this relationship is negative, with coefficient of -0.057879 . However, TANG is not statistically significant at $10 \%$ level.

Theoretically, there are some arguments supporting the positive relationship between growth opportunities (PB ratio) and leverage, as many analysts believe that companies with high growth opportunities face lower interest costs, resulting in higher financial leverage ratio. However, the results of the data analysis do not support this belief; particularly the coefficient of growth opportunities (PB ratio) and leverage is -0.013707 . The relationship between PB ratio and leverage is highly statistically significant at $1 \%$ level.

Regarding to tax perspective, it is expected a positive relationship between taxes and leverage. In fact, interest expenses are tax deductible, which means higher interest expenses, lower tax. The positive impact of tax on leverage is realized in our model, with coefficient of 0.052724 . However, the relationship between TAX and leverage is not statistically significant at $10 \%$ level. However, because volatility is perceived to be a risk's proxy of a company and is, therefore, predicted to be negatively related to leverage. The data analysis in my research also implies a negative relationship between these two variables (with coefficient of -0.831098 ), but it is not significantly related.

Regard to industry classification, the results show a statistically significant relationship between industry dummies and leverage in industry $\mathrm{D}_{4}$ (Mining of Raw Materials), which demonstrates a negative highly impact on leverage with coefficient of -0.189611 . $\mathrm{D}_{4}$ is highly statistically significant at $1 \%$ level. On the other hand, companies which are classified to industries $\mathrm{D}_{1}$ (Production and Distribution of Electricity, Gas, and Water), $\mathrm{D}_{2}$ (Retail), and $\mathrm{D}_{3}$ (Manufacturing) exhibit lower impact on leverage, with coefficients of 0.026596, -0.046922 , and -0.018865 respectively. This shows that the decision of creating dummy variables in this research is reasonable and a right choice.

In summary, regarding the statistical analysis results, in comparison to theoretical findings, there are some similarities as well as differences in our findings as described in the Table 8 below: 
Table 8

Comparison of Theoretical and Empirical Findings and Research Outcomes

\begin{tabular}{llllll}
\hline & $\begin{array}{l}\text { Theoretical } \\
\text { prediction }\end{array}$ & G7 countries & Developed countries $\begin{array}{l}\text { Developing } \\
\text { countries }\end{array}$ & $\begin{array}{l}\text { Findings of my } \\
\text { research }\end{array}$ \\
\hline Size & $+/-$ & $+(-)^{*}$ & $-(+)^{*}$ & $+(-)^{*}$ & + \\
Profitability & $+/-$ & $-(+)^{*}$ & $-(+)^{*}$ & - & - \\
Tangibility & + & + & + & $-(+)^{*}$ & - \\
Growth opportunities & - & - & $-(+)$ & $\left.*^{*}+\right)^{-}$ & - \\
Tax & + & & & $-(+)^{*}$ & + \\
Volatility & $+/-$ & & $-(+)$ & $-(+)^{*}$ & - \\
\hline
\end{tabular}

Notes. * Bracket means less often.

\section{Leverage Level Comparisons}

All the companies are classified into four groups of business sector according to dummy variables. The calculations of leverage for each group of companies in 2016 are as presented in Table 9 below.

Table 9

Leverage Level of Companies Grouped in four Industries

\begin{tabular}{ll}
\hline Industries & Average financial leverage \\
\hline Production and distribution of electricity, gas, and water industry & $76.91 \%$ \\
Retail industry & $68.28 \%$ \\
Manufacturing industry & $67.37 \%$ \\
Mining of raw materials industry & $43.35 \%$ \\
\hline
\end{tabular}

The Figure 5 below presents better the differences between average financial leverage of these four groups of industries.

\section{FINANCIAL LEVERAGE}

$90.00 \%$

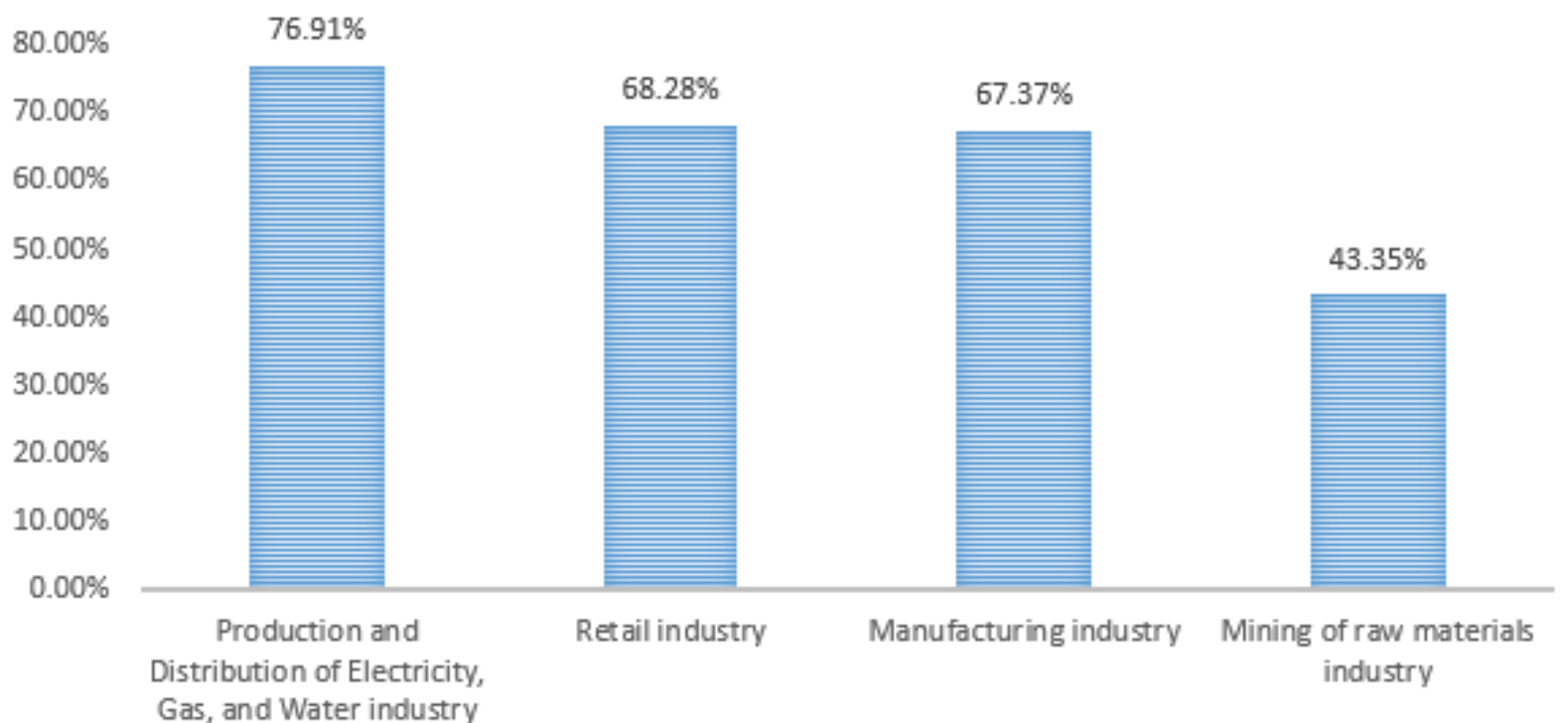

Figure 5. Financial leverage. 
As seen, debt financing holds a considerable role in business of UK companies. Among four industries, in average, mining industry experienced lowest financial average in 2016, less than 50\% and production and distribution of electricity, gas, and water industry witnessed a highest financial leverage which is more than $75 \%$. The other two industries utilised around $67-68 \%$ of debt in their total capital. In comparison to other industries, companies in mining of raw materials industry did not use much debt to finance their business. This result further supports the negative relationship found in regression model as presented previously.

There can be various reasons for such differences in the average level of financial leverage of different industries in the UK. Generally, it may be reasonable to say that companies in production and distribution of electricity, gas, and water industry in the UK could be in better condition to approach fund providers due to the relative stability in their business in compared to others, meaning more stable cash flow to meet payment (interests and principals) commitment. By retaining such high level of debt, these companies can lower their cost of capital and utilise tax saving benefits. However, the level of more than $75 \%$ of debt in total capital structure appears to be relatively high, and could lead to financial distress situation if there is not good management of cash flow.

The comparison results imply that there may not be difficulties in approaching commercial banks for loans, which is different from the situation in developing countries where there are always barriers for firms to borrow money, especially the requirement on collateral. When firms can easily raise debt to finance their new good projects, earnings can be spent on other purposes such as paying out as dividends to shareholders. This, therefore, can make the company stock appear to become more attractive to investors who are preferred regular income from investment, helping retain the stability of stock price in security market.

Possibly, the policy of retaining a low base rate of the Bank of England (which is reviewed in the introduction) has been one of important motivations for the UK companies to utilise much of debt in their capital structure. However, the increase in the interest rate level in the country (that is estimated to come soon because the record low of $0.25 \%$ has generated many other concerns to the economy) may cause significant changes in coming years. Especially, the new UK restriction on corporate interest tax relief since middle 2017 could also be significant affecting matter on the decision of using debt of companies in the future. This therefore can be a great topic for studying with particular focus on analysing the effect of policies on debt usage of companies in the economy.

\section{Discussion of Findings}

Our findings have certain indications to market about capital financing decisions of UK companies that can provide useful information for companies themselves as well as other external stakeholders in decision-making. First, among different determinants of capital structure, business sector should be the first factor of consideration. For example, the decision of companies in mining of raw material industry with regards to the use of debt is greatly affected by industry average level and these companies tend to use less debt than companies in other industries. In 2006, mining of raw materials companies was lower than the average level of all companies of FTSE 100 (63.97\%).

Second, growth opportunity as measured by P/B ratio is another important factor for UK companies to determine leverage level. In particular, high growth opportunities would lead to low level of leverage. There can be various reasons for such relationship in which what the most significant should mention is about the better chance for companies in the UK in approaching with the other source of capital. With high growth 
opportunities companies, they may prefer raising equity fund to increasing debt even the cost of equity is higher than the cost of debt as they do not want to face higher level of risk as well as the burden originated from regular interest payments or other responsibilities from covenant protection of the lenders, especially when cash inflow is limited due to the investment in positive NPV projects. Stated differently, they want to be able to focus on creating value in the future rather than being fancy with the tax saving benefit of debt. Nevertheless, the choice of using less debt in companies having good investment opportunities in the UK suggests that they have better chances to reduce cost of capitals by adding more debt in capital structure given the consideration of drawbacks and benefits of this funding source. Another possible reason is the preference of such companies in putting priority on using retained earnings rather than raising fund from creditors.

The other less important factors include size, profitability, level of tangible assets, tax, and volatility. Although there can be a tendency in the UK that larger firms (higher sales) would use more debt, the size of the company may be no longer considerably important to both creditors and corporations themselves in the UK. This may help generate a more robust financial system where firms at all sizes can have better access to fund in order to finance their business when they need to raise fund to finance good projects.

With regards to profitability, despite of the fact that it cannot confirm the significance of the negative relationship between profitability and leverage of UK companies, the large absolute value of coefficient (in comparison to that of other factors) implies a possible great impact of profitability on decision of using debt in some cases when firms would use retained earnings to finance their new projects.

The significance of negative relationship between the level of tangible assets and leverage is not found with the UK companies in this research. This indicates that in the UK fund providers (banks) do not consider tangible assets to be an important factor in making financing decision even they could be quickly and easily liquidated. The business plan or future prospect of the company is probably much more critical to the banks in the UK than the matter of collecting fund through the liquidation of companies' tangible assets. This is much different from the condition in many developing countries where level of tangible assets is always placed at the top important requirement when firms want to approach banks to borrow money.

Corporation tax system in the UK is possibly a motivation for companies in the country to consider using debt financing to take advantage of tax deductible. Nevertheless, the level of impact is not among critical ones. This indicates the changes in financial management practice of the UK firms today compared to that in the past when tax shield advantage was always reported as a great influential effect.

In the UK, only using standard deviation of ROA as the proxy to estimate the risk level of the company seems not powerful enough in testing the effect on the leverage level. It could be better to understand different types of risk such as systematic vs. unsystematic risk and the characteristics of each company as different companies will expose to various risks at different levels. This understanding can help choose the more appropriate risk proxy to include in the model. The above analysis helps us understand better the UK situation given the consideration of all main capital structure theories as described below. 
Table 10

Capital Structure Theories and the Situation in the UK

\begin{tabular}{|c|c|c|}
\hline Theories & Indication & The UK situation \\
\hline $\begin{array}{l}\text { (1) Modigliani and } \\
\text { Miller (1958) }\end{array}$ & Capital structure irrelevance proposition & $\begin{array}{l}\text { Capital structure is relevant with companies in the UK since } \\
\text { companies in different industries tend to employ a different } \\
\text { capital structure, depending on business nature. Especially, } \\
\text { statistically significant relationship between industry } \\
\text { dummies and leverage in industry D4 (Mining of Raw } \\
\text { Materials) is founded. }\end{array}$ \\
\hline $\begin{array}{l}\text { (2) Static trade off } \\
\text { theory }\end{array}$ & $\begin{array}{l}\text { Optimal capital structures of firms are affected } \\
\text { by the trade-off between costs and benefits } \\
\text { when using debt and equity. The main } \\
\text { advantage of debt is tax shield but the prominent } \\
\text { disadvantage is financial distress cost. }\end{array}$ & $\begin{array}{l}\text { This theory is only applicable in certain cases because } \\
\text { although a positive relationship between tax and leverage is } \\
\text { found in this research, the relationship is not statically } \\
\text { significant. }\end{array}$ \\
\hline $\begin{array}{l}\text { (3) Dynamic trade } \\
\text { off theory }\end{array}$ & $\begin{array}{l}\text { The appropriate financing choice typically } \\
\text { relies on the financing margin that is estimated } \\
\text { in the coming period. }\end{array}$ & $\begin{array}{l}\text { There is no powerful evidence from findings of this research } \\
\text { to conclude the workability of this theory in the UK because } \\
\text { it is required to select a better variable to measure the } \\
\text { estimated financing margin of companies. }\end{array}$ \\
\hline $\begin{array}{l}\text { (4) Pecking order } \\
\text { theory }\end{array}$ & $\begin{array}{l}\text { Companies prefer employing internal fund such } \\
\text { as retained earnings or excess liquid assets to } \\
\text { external to finance investment opportunities. }\end{array}$ & $\begin{array}{l}\text { This theory seems to illustrate well the situation of the UK } \\
\text { companies because the findings of the significantly positive } \\
\text { relationship between leverage and growth opportunities and } \\
\text { the negative relationship between profitability and leverage } \\
\text { reveal a preference of the UK companies in utilising retained } \\
\text { earnings to finance their businesses or good NPV investment } \\
\text { projects. }\end{array}$ \\
\hline $\begin{array}{l}\text { (5) Market timing } \\
\text { theory }\end{array}$ & $\begin{array}{l}\text { Stock price fluctuations in the market influence } \\
\text { companies' funding decision, capital structure. } \\
\text { Thus, there is no optimal capital structure. }\end{array}$ & $\begin{array}{l}\text { There is no evidence from findings of this research to } \\
\text { conclude the workability of this theory in the UK because } \\
\text { there is no observed variable about stock price fluctuation of } \\
\text { companies listed in the UK included in the testing models. }\end{array}$ \\
\hline
\end{tabular}

The above finding as presented in Table 10 helps provide suggestions to companies in the UK as well as outsiders, such as investors, market analysts, fund providers etc., in terms of behaviours of companies in different industries.

Firstly, companies in production and distribution of electricity, gas, and water industry should not further increase their debt to finance new projects. They should consider the application of pecking order theory that companies prefer employing internal fund such as retained earnings or excess liquid assets to external to finance investment opportunities. This means that when outsiders notice an increase in borrowing from these companies, they should avoid investing in stock of such companies because total risk would be higher with the additional debt, possibly leading to high financial distress.

Secondly, companies in retail and manufacturing industry should consider the application of static trade off theory that optimal capital structures of firms are affected by the trade-off between costs and benefits when using debt and equity and the main advantage of debt is tax shield but the prominent disadvantage is financial distress cost. The main reason is that these companies can decide to increase, retain, or decrease debt proposition in total capital structure, depending on the risk profile of new investment opportunities.

Lastly, with companies in mining of raw materials industry, funding decision may alter from firm to firm. For example, if a particular company in the industry follows pecking order theory, preferring using internal fund such as retained earnings or excess liquid assets to using external to finance investment opportunities, this indicates that they consider adding more debt is risky. However, if another company in the industry decides to raise more debt in their total capital structure, following the static trade off theory, this would mean that the company wants to take advantage of debt which is tax shield. 


\section{Empirical Results and Comparisons With Previous Studies}

It can be seen that the findings of this research are supportive as well as conflict with some empirical studies that are reviewed previously in the literature review section. The understanding of such matter is important as it helps obtain wider views about financing decision of companies and find interesting topics/areas for further studies. The Table 11 below shows more details of the comparison and interpretation where needed.

Table 11

\section{Research Findings and Previous Empirical Studies Comparison}

\begin{tabular}{|c|c|c|c|}
\hline Determinants & Authors & Previous studies & Results \\
\hline \multirow[t]{4}{*}{ Company size } & $\begin{array}{l}\text { Rajan and Zingales } \\
(1995)\end{array}$ & $\begin{array}{l}\text { Arguments: } \\
\text { Bigger organisations tend to be more diversified } \\
\text { and fail less often, so size may be an inverse } \\
\text { proxy for the probability of bankruptcy. If so, } \\
\text { size should have a positive impact on the supply } \\
\text { debt. } \\
\text { Nevertheless, size may convey other information } \\
\text { to outside investors that could influence their } \\
\text { choice of equity over debt. } \\
\text { The use of different measurement may lead to } \\
\text { different findings. } \\
\text { Conclusion: The level of statistical significance } \\
\text { reported from the empirical tests for the } \\
\text { relationship of such variables is weak. }\end{array}$ & $\begin{array}{l}\text { Investigation results of this research } \\
\text { support the conclusion of these authors. } \\
\text { This means that in the case of UK } \\
\text { companies, size (that has proxy by } \\
\text { sales) should not hold any significant } \\
\text { role affecting the choice of debt vs. } \\
\text { equity. That means there should not be } \\
\text { any signal related to the size of firms } \\
\text { when they determine to increase or } \\
\text { decrease leverage in capital structure. }\end{array}$ \\
\hline & Graham et al. (1998) & $\begin{array}{l}\text { Large firms experience less risk of bankruptcies, } \\
\text { so that they have better approaches to various } \\
\text { funding sources in the market. }\end{array}$ & \multirow{2}{*}{$\begin{array}{l}\text { Although the data analysis cannot fully } \\
\text { support this argument, in general it is } \\
\text { still a reasonable explanation for the } \\
\text { high leverage proportion in capital } \\
\text { structure of large companies. }\end{array}$} \\
\hline & Sayilgan et al. (2006) & $\begin{array}{l}\text { Large firms may receive protection from the } \\
\text { government, meaning better changes to borrow } \\
\text { money in the market. }\end{array}$ & \\
\hline & $\begin{array}{l}\text { Harris and Raviv } \\
\text { (1991) }\end{array}$ & $\begin{array}{l}\text { Large firms with more tangible assets are able to } \\
\text { offer market participants with more information } \\
\text { resulting better opportunities to meet new } \\
\text { funding providers’ needs. }\end{array}$ & $\begin{array}{l}\text { This follows pecking order theory and } \\
\text { may be applicable in some cases of big } \\
\text { corporation in the UK. }\end{array}$ \\
\hline \multirow[t]{2}{*}{ Profitability } & Bauer (2004) & $\begin{array}{l}\text { More profitable organizations should utilise } \\
\text { more debt because this could help discipline } \\
\text { managers through the avoidance of investing on } \\
\text { projects lack of efficiency by paying out cash. }\end{array}$ & $\begin{array}{l}\text { This suggests another advantage of debt } \\
\text { that is often less mentioned. Although } \\
\text { there is no strong clue from this study to } \\
\text { support this conclusion, it is a good } \\
\text { advice for more studies that focus on } \\
\text { this particular topic in the UK in the } \\
\text { future. }\end{array}$ \\
\hline & $\begin{array}{l}\text { Myers and Majluf } \\
(1984)\end{array}$ & $\begin{array}{l}\text { More money-making companies have less need } \\
\text { for external source of funding, meaning a } \\
\text { negative connection between profitability and } \\
\text { leverage. }\end{array}$ & $\begin{array}{l}\text { This conclusion is not supported by my } \\
\text { research. }\end{array}$ \\
\hline \multirow[b]{2}{*}{ Tangibility } & $\begin{array}{l}\text { Titman and Wessels } \\
(1988)\end{array}$ & $\begin{array}{l}\text { Tangible has advantage over intangible assets by } \\
\text { helping firms boost leverage based on the } \\
\text { collateral value. }\end{array}$ & \multirow{2}{*}{$\begin{array}{l}\text { This could be the case in certain } \\
\text { business industries in the UK; however, } \\
\text { this research results are not strong } \\
\text { enough to confirm this benefit of } \\
\text { tangible assets. }\end{array}$} \\
\hline & Booth et al. (2001) & $\begin{array}{l}\text { There is a positive connection between } \\
\text { tangibility and indebtedness since the more } \\
\text { tangible assets that firms own in terms of value } \\
\text { and number, the better they can secure debt, } \\
\text { helping avoid the leakage of future profits } \\
\text { information. }\end{array}$ & \\
\hline
\end{tabular}


(table 11 continued)

\begin{tabular}{|c|c|c|c|}
\hline Determinants & Authors & Previous studies & Results \\
\hline \multirow{5}{*}{$\begin{array}{l}\text { Growth } \\
\text { opportunities }\end{array}$} & Myers (1977) & $\begin{array}{l}\text { Companies experiencing good growth should be } \\
\text { financed by more equity. This is because a } \\
\text { greater leveraged firm could be more likely to } \\
\text { lose profitable investment chances. }\end{array}$ & \multirow{3}{*}{$\begin{array}{l}\text { The finding of this research supports } \\
\text { this argument with the case of the UK } \\
\text { companies as the significantly negative } \\
\text { relationship between PB ratio and } \\
\text { leverage was found. }\end{array}$} \\
\hline & $\begin{array}{l}\text { Rajan and Zingales } \\
(1995)\end{array}$ & $\begin{array}{l}\text { Companies with larger market-to-book ratio may } \\
\text { witness higher financial distress costs which, in } \\
\text { turn, lead to a negative relationship with } \\
\text { leverage. }\end{array}$ & \\
\hline & $\begin{array}{l}\text { Fama and French } \\
(2000)\end{array}$ & $\begin{array}{l}\text { Companies with high investment opportunities } \\
\text { do not consider debt as a priority when seeking } \\
\text { fund to finance such investment plans. }\end{array}$ & \\
\hline & Jensen (1986) & $\begin{array}{l}\text { The more growth opportunities presented to } \\
\text { companies, the more the indebtedness could be. } \\
\text { This is to reduce the agency costs between } \\
\text { managers and shareholders since the use of debt } \\
\text { financing could help discipline managers. }\end{array}$ & $\begin{array}{l}\text { This argument is based on the theory of } \\
\text { agency costs that could be a good topic } \\
\text { for future investigation. However, the } \\
\text { analysis of collected data in this } \\
\text { research is not supporting this } \\
\text { viewpoint. }\end{array}$ \\
\hline & Song (2005) & $\begin{array}{l}\text { High growth opportunities will require more } \\
\text { amount of capital that creates motivations for } \\
\text { managers to seek external funding source } \\
\text { bringing better earnings to creditors. }\end{array}$ & $\begin{array}{l}\text { This could be an illustration for some } \\
\text { cases but not be able to confirm by this } \\
\text { research finding. }\end{array}$ \\
\hline \multirow{4}{*}{ Tax } & $\begin{array}{l}\text { Gertler and Hubbard } \\
\text { (1989) }\end{array}$ & $\begin{array}{l}\text { There could be an encouragement to } \\
\text { corporations generated from the tax system in } \\
\text { order to "absorb more business cycle risk than } \\
\text { they would otherwise". This is because of the } \\
\text { generation of "a relative subsidy to debt finance" } \\
\text { and debt renegotiation to retain debt financing in } \\
\text { the capital structure. }\end{array}$ & $\begin{array}{l}\text { There is no evidence from this research } \\
\text { but it is an interesting area that future } \\
\text { investigators could consider. }\end{array}$ \\
\hline & Faccio and Xu (2015) & $\begin{array}{l}\text { Taxes were significant determinants of capital } \\
\text { structure. }\end{array}$ & $\begin{array}{l}\text { This cannot be confirmed based on my } \\
\text { research outcome. }\end{array}$ \\
\hline & $\begin{array}{l}\text { Fama and French } \\
\text { (1998) }\end{array}$ & There are not net tax benefits of debt. & $\begin{array}{l}\text { This seems to be the same with } \\
\text { companies in the UK as no significant } \\
\text { relationship between tax and leverage } \\
\text { was found. }\end{array}$ \\
\hline & $\begin{array}{l}\text { Dwenger and Steiner } \\
\text { (2009) }\end{array}$ & $\begin{array}{l}\text { An increase by } 10 \% \text { of effective tax rate could } \\
\text { lead to an increase by } 5 \% \text { in the financial } \\
\text { leverage. }\end{array}$ & $\begin{array}{l}\text { Need further examination for the UK } \\
\text { companies, especially when there is a } \\
\text { change in the rate of corporation tax, } \\
\text { reduction from } 28 \% \text { in } 2010 \text { to } 20 \% \\
\text { from April this year, and from } 2017 \text { it } \\
\text { will be reduced further to } 19 \% \text { then to } \\
18 \% \text { in } 2020 \text { plus with the new rules } \\
\text { would increase compliance burden with } \\
\text { highly geared groups significantly } \\
\text { affected. }\end{array}$ \\
\hline \multirow[t]{2}{*}{ Volatility } & $\begin{array}{l}\text { Huang and Song } \\
(2002)\end{array}$ & $\begin{array}{l}\text { The systematic risk of equity reduces when there } \\
\text { is an increase in variance of firms' assets value } \\
\text { meaning that “business risk is expected to be } \\
\text { positively related to leverage”. }\end{array}$ & $\begin{array}{l}\text { An interesting research area for future } \\
\text { works. }\end{array}$ \\
\hline & Halov et al. (2009) & $\begin{array}{l}\text { Volatility of risk could be an important element } \\
\text { in justifying firms’ capital structure decision. }\end{array}$ & $\begin{array}{l}\text { My research cannot confirm this } \\
\text { conclusion as the significant } \\
\text { relationship between leverage and } \\
\text { standard deviation of ROA was not } \\
\text { found. }\end{array}$ \\
\hline
\end{tabular}


(table 11 continued)

\begin{tabular}{|l|l|l|l|}
\hline Determinants & Authors & Previous studies & Results \\
\hline $\begin{array}{l}\text { Business } \\
\text { sector }\end{array}$ & $\begin{array}{l}\text { Harris and Raviv } \\
\text { (1991) }\end{array}$ & $\begin{array}{l}\text { Drugs, instruments, electronics, and food have } \\
\text { consistently low leverage while paper, textile } \\
\text { mill products, steel, airlines, and cement have } \\
\text { consistently large leverage. }\end{array}$ & $\begin{array}{l}\text { Although the industry classification in } \\
\text { my research is different from that of } \\
\text { these authors, we all find the same } \\
\text { conclusion that business sector has } \\
\text { determining role in capital structure of } \\
\text { firms. }\end{array}$ \\
\hline & $\begin{array}{l}\text { Titman and Wessels } \\
\text { (1988) }\end{array}$ & $\begin{array}{l}\text { Manufacturer of machines and equipment should } \\
\text { employ less debt in capital structure as using too } \\
\text { much debt could influence their sustainability. }\end{array}$ & $\begin{array}{l}\text { My finding supports this conclusion as a } \\
\text { significant negative relationship was } \\
\text { found. }\end{array}$ \\
\hline & $\begin{array}{l}\text { Pacheco and Tavares } \\
\text { (2015) }\end{array}$ & $\begin{array}{l}\text { Firms in this footwear sector should follow } \\
\text { pecking order when determining changes in their } \\
\text { capital structure. }\end{array}$ & My research supports this conclusion. \\
\hline
\end{tabular}

The above analysis supplies a valuable source of comparison between the UK situation and others with regards to capital structure's determinants through the lens of worldwide researchers. This is helpful not only in gaining a deeper insight but also in presenting many attracting areas of researching for the UK companies.

\section{Concluding Remarks}

This study aims at investigating main determinants of capital structure of the UK firms with three objectives: (1) analysing the impact of key factors on debt financing decision (leverage) of listed firms in FTSE 100, (2) analysing the differences in capital structure of companies in different industries in the UK; and (3) understanding how various capital structure theories fit the situation of the UK.

The research starts with the review of previous papers to gain general background and knowledge important to the analysis. First of all, the review of the evolution of various capital structure theories was carried out. Modigliani and Miller capital structure theory was the first developed based on a series of assumptions such as there are no taxes and transaction costs, no bankruptcy costs etc. They argued that in a perfect market, financial structure of company has no impact on its value, meaning that debt-to-equity ratio and company's total value are independent with each other. Critically evaluating the Modigliani and Miller works led to the existence of trade-off theory arguing the decision of financing choice is the combination of the evaluation of benefits and costs associated with different leverage plans. Pecking order theory and the market timing theory are the two other schools of thought about capital structure in which the first one means that companies prefer employing internal fund such as retained earnings or excess liquid assets to external to finance investment opportunities and the other indicates that the issue of share is determined by the perception towards the stock price in the market. The rest of the reviewing previous studies focused on the analyses of researches examining different determinant of capital structure of firms worldwide over the years.

Then, the chosen methods and modelling approaches to help obtain research aim and objectives are quantitative research and regression analysis with the data set including all companies listed in FTSE 100 in 2016. The final model for the OLS estimation has six independent variables (size, profitability, tangibility, growth opportunities, tax, and volatility) and four industry classification dummy variables and the dependent variable is financial leverage.

The analysis of collected data for six independent variables indicates that (i) size and leverage are positively related but such positive relationship is not significant; (ii) profitability and leverage are negatively related but such negative relationship is not significant; (iii) level of tangible assets and leverage are negatively 
related but such negative relationship is not significant; (iv) growth opportunities and leverage are negatively correlated and the negative relationship is highly statistically significant; (v) tax and leverage are positively related but the relationship is not statistically significant; and (vi) volatility and leverage are negatively related but the relationship is not statistically significant.

In terms of industry classification, the results show a statistically negative significant relationship between industry dummies and leverage in industry $\mathrm{D}_{4}$ (Mining of Raw Materials), but companies which are classified to industries $\mathrm{D}_{1}$ (Production and Distribution of Electricity, Gas, and Water), $\mathrm{D}_{2}$ (Retail), and $\mathrm{D}_{3}$ (Manufacturing) exhibit lower impact on leverage.

In terms of the analysis about the relevance of five different capital structures in the UK market, this research has a number of interesting findings. Firstly, the pecking order theory, indicating that companies prefer employing internal fund such as retained earnings or excess liquid assets to external to finance investment opportunities, seems suit well with the situation of the UK companies. This is because of the findings about the significantly positive relationship between leverage and growth opportunities and the negative relationship between profitability.

Modigliani and Miller theory, implying the irrelevance proposition of capital structure, does not work in the situation of companies in the UK. Static trade-off theory which mentions the existence of optimal capital structures of firms that are affected by the trade-off between costs and benefits when using debt and equity is only applicable in certain cases in the UK. Dynamic trade off theory, showing that the appropriate financing choice typically relies on the financing margin that is estimated in the coming period and market timing theory which is about stock price fluctuation in the market influencing companies' capital structure, are not supported by findings of this resort for the UK market.

\section{References}

Abor, J., \& Biekpe, N. (2009). How do we explain the capital structure of SMEs in sub-Saharan Africa? Evidence from Ghana. Journal of Economic Studies, 36(1), 83-97.

Acaravci, S. (2015). The determinants of capital structure: Evidence from the Turkish manufacturing sector. International Journal of Economics and Financial Issues, 5(1), 158-171.

Alti, A. (2006). How persistent is the impact of market timing on capital structure? The Journal of Finance, LXI(4), 1681-1710.

Bas, T., Muradoglu, G. and Phylaktis, K. (2009). Determinants of Capital Structure in Developing Countries. Retrieved from https://www.researchgate.net/publication/228465937_Determinants_of_Capital_Structure_in_Developing_Countries (accessed 12 December 2017)

Bauer, P. (2004). Determinants of capital structure: Empirical evidence from the Czech Republic. Czech Journal of Economics and Finance, 54, 2-21.

BBC News. (August 2016). UK interest rates cut to 0.25\%. Retrieved from http://www.bbc.com/news/business-36976528 (accessed August 2017)

Booth, L., Aivazian, V., Demirguc-Kunt, A., \& Maksimovic, V. (2001). Capital structure in developing countries. Journal of Finance, 56, 87-130.

Brennan, M. J., \& Schwartz, E. S. (1984). Optimal financial policy and firm valuation. Journal of Finance, 39, 593-607.

Brounen, D., de Jong, A., \& Koedijk, K. (2006). Capital structure policies in Europe: Survey evidence. Journal of Bank and Finance, 30(5), 1409-1442.

Bryman, A., \& Bell, E. (2011). Business research methods (3rd ed.). Oxford: Oxford University Press Inc.

De Jong, A., Kabir, R., \& Nguyen, T. T. (2008). Capital structure around the world: The roles of firm-and country-specific determinants. Journal of Bank and Finance, 32(9), 1954-1969.

Drobetz, W. \& Fix, R. (2005). What are the Determinants of the Capital Structure? Evidence from Switzerland. Swiss Journal of Economics and Statistics (SJES), 141(I), 71-113. 
Faccio, M., \& Xu, J. (2015). Taxes and capital structure. Journal of Financial and Quantitative Analysis, 50(3), 277-300.

Fama, E. F., \& French, K. R. (1998). The corporate cost of capital and the return on corporate investment. Center for Research in Security Prices, University of Chicago, Working Paper.

Fama, E. F., \& French, K. R. (2002). Testing trade-off and pecking order predictions about dividend and debt. Review of Financial Studies, 15(1), 1-33.

Fattouh, B., Harris, L., \& Scaramozzino, P. (2002). Capital structure in South Korea: A quantile regression approach. Royal Economic Society Annual Conference, 70, 1-34.

Financial Times. (2017). How Brexit will affect sectors of the UK economy. Retrieved from https://www.ft.com/content/602f3674-573a-11e7-9fed-c19e2700005f (Accessed Septmebr 2018)

Gaud, P., Jani, E., Hoesli, M., \& Sarig, O. (2005). The capital structure of Swiss companies: An empirical analysis using dynamic panel data. European Financial Management, 11, 51-59.

Gertler, M., \& Hubbard, R. (1989). Taxation, corporate capital structure, and financial distress. NBER Working Paper, No. 3202.

Giannetti, M. (2003). Do better institutions mitigate agency problems? Evidence from corporate finance choices. Journal of Finance and Quantitative Analysis, 47(1), 23-56.

Goldstein, R., Ju, N., \& Leland, H. (2001). An ebit-based model of dynamic capital structure. Journal of Business, 74, 483-512.

Graham, J. R., \& Harvey, C. (2001). The theory and practice of corporate finance: evidence from the field. Journal of Financial Economics, 60, 187-224.

Graham, J. R., Lemmon, M., \& Schallheim, J. (1998). Debt, leases, taxes and the endogeneity of corporate tax status. Journal of Finance, 53, 131-162.

Halov, N., Heider, F., \& Kose, J. (2009). Capital structure and volatility of risk. European Central Bank. Retrieved from http://myweb.lmu.edu/ccfc/index_files/fall09/halovcapstruc.pdf (accessed July 2017)

Harris, M., \& Raviv, A. (1991). The theory of capital structure. Journal of Finance, 46, 297-356.

HM Revenue \& Customs, HM Treasury. (2016). Tax deductibility of corporate interest expense: Consultation (October 2015). Retrieved

https://www.gov.uk/government/consultations/tax-deductibility-of-corporate-interest-expense/tax-deductibility-of-corporateinterest-expense-consultation (accessed August 2017)

Huang, S. G., \& Song, F. M. (2002). The determinants of capital structure: Evidence from China. Hong Kong Institute of Economics and Business Strategy, Working Paper, 2002, No. 1042.

Jensen, M. C. (1986). Agency costs of free cash-flow, corporate finance, and takeovers. American Economic Review, 76, 323-329.

Jensen, M. C., \& Meckling, W. H. (1976). Theory of the firm: Managerial behavior, agency costs and ownership structure. Journal of Financial Economics, 3, 305-360.

Jin, X. (2012). Profitability and capital structure: Evidence from import penetration. The Journal of Financial Economics, 106, 427-446.

Levene, T. (2015). Investing for dummies—UK (4th ed.). Hoboken, NJ: John Wiley and Sons Ltd.

Lopez-Garcia, J., \& Sogorb-Mira, F. (2008). Testing trade-off and pecking order theories financing SMEs. Small Business Economics, 31, 117-136.

Modigliani, F., \& Miller, M. H. (1958). The cost of capital, corporate finance and the theory of investment. American Economic Review, 48, 261-297.

Myers, S. C. (1977). Determinants of corporate borrowing. Journal of Financial Economics, 5, 147-175.

Myers, S. C., \& Majluf, N. S. (1984). Corporate financing and investment decisions when firms have information that investors do not have. Journal of Financial Economics, 13, 187-221.

Myers, S. C., \& Rajan, R. G. (1998). The paradox of liquidity. Quarterly Journal of Economics, 113(3), 733-771.

Odendahl, C. (2014). The eurozone's real interest rate problem. Retrieved from http://www.cer.eu/insights/eurozones-real-interest-rate-problem (accessed August 2017)

Ozkan, A. (2001). Determinants of capital structure and adjustments to long run target: Evidence from UK company panel data. Journal of Business Finance and Accounting, 28, 175-195.

Pacheco, L., \& Tavares, F. (2015). Capital structure determinants of Portuguese footwear sector SMEs: Empirical evidence using a panel data. Tékhne, 13(2), 145-157.

Rajan, R. G., \& Zingales, L. (1995). What do we know about capital structure? Some evidence from international data. Journal of Finance, 5, 1421-1460. 
Ramalho, J., \& Silva, J. (2013). Functional form issues in the regression analysis of corporate capital structure. Empirical Economics, 44(2), 799-831.

Sayilgan, G., Karabacak, H., \& Kucukkocaoglu, G. (2006). The firm-specific determinants of corporate capital structure: Evidence from Turkish panel data. Investment Management and Financial Innovations, 3, 125-137.

Sbeti, W. M., \& Moosa, I. (2012). Firm-specific factors as determinants of capital structure in the absence of taxes. Appl. Financial Econ., 22(3), 209-213.

Shah, A., \& Hijazi, T. (2004). The determinants of capital structure of stock exchange listed non-financial firms in Pakistan. The Pakistan Development Review, 43(4), 605-618.

Skrivanek, S. (2009). The use of dummy variables in regression analysis. MoreSteam. Retrieved from https://www.moresteam.com/whitepapers/download/dummy-variables.pdf (accessed August 2017)

Song, H. S. (2005). Capital structure determinants—an empirical study of Swedish companies. Working Paper, The Royal Institute of Technology, Stockholm, November 19-20.

Titman, S. (1984). The effect of capital structure on a firm's liquidation decision. Journal of Financial Economics, 13, $137-151$.

Titman, S., \& Wessells, R. (1988). The determinants of capital structure choice. The Journal of Finance, 43, 1-19.

Vo, X. (2017). Determinants of capital structure in emerging markets: Evidence from Vietnam. International Business and Finance, 40, 105-113.

Walker, I., Self, H., \& Christian, J. (June 2017). New UK restriction on corporate interest tax relief. Retrieved from https://www.out-law.com/en/articles/2017/june/new-uk-restriction-on-corporate-interest-tax-relief/ (accessed August 2017)

Zietlow, J., Hankin, J., \& Seidner, A. (2007). Financial management for non-profit organisations: Policies and practices. Hoboken, NJ: Wileys. 
Appendices

Appendix A: Full Data Set

\begin{tabular}{|c|c|c|c|c|c|c|c|c|}
\hline & & Size & Profitability & Tangibility & $\begin{array}{l}\text { Growth } \\
\text { opportunities }\end{array}$ & Tax & Volatility & $\begin{array}{l}\text { Capital } \\
\text { structure }\end{array}$ \\
\hline III & 3i Group Plc. & 956,000 & $14.75 \%$ & $100.00 \%$ & 6 & $0.24 \%$ & $0.44 \%$ & $15.07 \%$ \\
\hline $\mathrm{ADM}$ & Admiral Group & $1,353,600$ & $5.73 \%$ & $96.66 \%$ & 2.18 & $30.03 \%$ & $1.65 \%$ & $88.03 \%$ \\
\hline AAL & Anglo American & $21,378,000$ & $6.12 \%$ & $93.59 \%$ & 11.61 & $26.60 \%$ & $4.58 \%$ & $51.49 \%$ \\
\hline ANTO & Antofagasta Holdings & $3,625,500$ & $3.32 \%$ & $98.91 \%$ & 5.37 & $37.64 \%$ & $2.64 \%$ & $37.99 \%$ \\
\hline AHT & Ashtead Group Plc. & $3,186,800$ & $14.19 \%$ & $84.13 \%$ & 3.95 & $34.52 \%$ & $1.21 \%$ & $67.84 \%$ \\
\hline $\mathrm{ABF}$ & $\begin{array}{l}\text { Associated British Foods } \\
\text { Plc. }\end{array}$ & $13,399,000$ & $9.57 \%$ & $88.15 \%$ & 9.86 & $21.21 \%$ & $1.13 \%$ & $37.39 \%$ \\
\hline AZN & AstraZeneca Plc. & $23,002,000$ & $7.84 \%$ & $37.24 \%$ & 8.39 & $4.11 \%$ & $3.57 \%$ & $73.34 \%$ \\
\hline $\mathrm{AV}$ & Aviva Plc. & $45,190,000$ & $0.01 \%$ & $100.00 \%$ & 4.17 & $28.00 \%$ & $0.84 \%$ & $89.31 \%$ \\
\hline BAB & $\begin{array}{l}\text { Babcock International } \\
\text { Group }\end{array}$ & $4,547,100$ & $6.94 \%$ & $47.53 \%$ & 5.28 & $12.84 \%$ & $0.52 \%$ & $56.09 \%$ \\
\hline $\mathrm{BA}$ & BAE Systems Plc. & $17,790,000$ & $7.59 \%$ & $50.97 \%$ & 1.09 & $18.51 \%$ & $1.55 \%$ & $84.92 \%$ \\
\hline BARC & Barclays Plc. & $25,308,000$ & $2.09 \%$ & $100.00 \%$ & 3.75 & $31.48 \%$ & $0.10 \%$ & $87.57 \%$ \\
\hline BDEV & Barratt Developments Plc. & $4,235,200$ & $10.41 \%$ & $86.10 \%$ & 3.97 & $19.35 \%$ & $3.57 \%$ & $37.52 \%$ \\
\hline BLT & BHP Billiton Plc. & $30,912,000$ & $-5.37 \%$ & $96.54 \%$ & 8.27 & $-14.49 \%$ & $7.36 \%$ & $49.50 \%$ \\
\hline $\mathrm{BP}$ & BP Plc. & $183,008,000$ & $-0.30 \%$ & $95.28 \%$ & 3.81 & $-107.49 \%$ & $3.85 \%$ & $63.22 \%$ \\
\hline BATS & $\begin{array}{l}\text { British American Tobacco } \\
\text { Plc. } \\
\end{array}$ & $14,751,000$ & $11.70 \%$ & $69.53 \%$ & 4.14 & $22.51 \%$ & $1.19 \%$ & $78.87 \%$ \\
\hline BLND & British Land Co. Plc. & 589,000 & $3.04 \%$ & $100.00 \%$ & 8.95 & $0.51 \%$ & $5.52 \%$ & $29.64 \%$ \\
\hline BT.A & BT Group Plc. & $24,062,000$ & $7.45 \%$ & $64.53 \%$ & 0.8131 & $18.95 \%$ & $1.57 \%$ & $80.33 \%$ \\
\hline BNZL & Bunzl Plc. & $7,429,100$ & $9.09 \%$ & $56.79 \%$ & 3.91 & $26.73 \%$ & $0.11 \%$ & $70.88 \%$ \\
\hline BRBY & Burberry Group Plc. & $2,766,000$ & $15.94 \%$ & $92.95 \%$ & 3.8 & $27.13 \%$ & $2.06 \%$ & $29.65 \%$ \\
\hline CCL & Carnival Plc. & $16,389,000$ & $7.82 \%$ & $89.25 \%$ & 24.66 & $1.73 \%$ & $2.10 \%$ & $41.96 \%$ \\
\hline CNA & Centrica Plc. & $27,102,000$ & $12.19 \%$ & $81.20 \%$ & 0.4564 & $23.97 \%$ & $5.73 \%$ & $87.01 \%$ \\
\hline $\mathrm{CCH}$ & Coca-Cola HBC AG & $6,219,000$ & $7.71 \%$ & $71.28 \%$ & 6.97 & $24.86 \%$ & $1.04 \%$ & $56.28 \%$ \\
\hline CPG & Compass Group Plc. & $19,605,000$ & $13.37 \%$ & $47.65 \%$ & 1.77 & $24.15 \%$ & $2.51 \%$ & $76.10 \%$ \\
\hline CTEC & ConvaTec Group Plc. & $1,688,300$ & $-3.63 \%$ & $30.89 \%$ & 0.5438 & $37.97 \%$ & $2.31 \%$ & $65.38 \%$ \\
\hline $\mathrm{CRH}$ & CRH Plc. & $27,104,000$ & $5.51 \%$ & $75.44 \%$ & 16.69 & $37.09 \%$ & $2.36 \%$ & $54.29 \%$ \\
\hline CRDA & Croda International Plc. & $1,243,600$ & $18.82 \%$ & $76.31 \%$ & 5.28 & $28.33 \%$ & $1.34 \%$ & $59.41 \%$ \\
\hline DCC & DCC Plc. & $12,445,034$ & $5.30 \%$ & $100.00 \%$ & 16.64 & $18.39 \%$ & $0.49 \%$ & $72.25 \%$ \\
\hline DGE & Diageo Plc. & $10,485,000$ & $9.98 \%$ & $56.58 \%$ & 4.1 & $17.35 \%$ & $0.77 \%$ & $64.27 \%$ \\
\hline DLG & $\begin{array}{l}\text { Direct Line Insurance } \\
\text { Group Plc. }\end{array}$ & $3,202,800$ & $3.49 \%$ & $94.97 \%$ & 1.93 & $26.61 \%$ & $1.34 \%$ & $75.09 \%$ \\
\hline EZJ & easyJet Plc. & $4,669,000$ & $9.05 \%$ & $90.61 \%$ & 5.89 & $13.74 \%$ & $2.21 \%$ & $50.74 \%$ \\
\hline EXPN & Experian Plc. & $4,335,000$ & $13.98 \%$ & $25.81 \%$ & 2.18 & $24.18 \%$ & $2.61 \%$ & $65.53 \%$ \\
\hline FERG & Ferguson Plc. & $14,430,000$ & $8.92 \%$ & $86.46 \%$ & 12.23 & $46.57 \%$ & $2.52 \%$ & $64.41 \%$ \\
\hline FRES & Fresnillo & $1,905,503$ & $15.79 \%$ & $100.00 \%$ & 3 & $40.83 \%$ & $9.03 \%$ & $36.68 \%$ \\
\hline GFS & G4S Plc. & $7,590,000$ & $7.49 \%$ & $62.68 \%$ & 0.4943 & $25.94 \%$ & $4.13 \%$ & $84.62 \%$ \\
\hline GKN & GKN Plc. & $8,822,000$ & $3.98 \%$ & $78.71 \%$ & 1.46 & $16.44 \%$ & $2.64 \%$ & $75.88 \%$ \\
\hline GSK & GlaxoSmithKline Plc. & $27,889,000$ & $4.14 \%$ & $58.12 \%$ & 0.3486 & $45.23 \%$ & $6.20 \%$ & $91.60 \%$ \\
\hline GLEN & Glencore Plc. & $173,833,000$ & $1.21 \%$ & $94.61 \%$ & 2.47 & $537.76 \%$ & $3.46 \%$ & $64.86 \%$ \\
\hline HMSO & Hammerson & 251,300 & $4.93 \%$ & $100.00 \%$ & 7.57 & $0.59 \%$ & $3.31 \%$ & $40.18 \%$ \\
\hline $\mathrm{HL}$ & Hargreaves Lansdown Plc. & 326,536 & $25.63 \%$ & $99.02 \%$ & 0.647 & $19.02 \%$ & $5.96 \%$ & $70.15 \%$ \\
\hline HSBA & HSBC Holdings Plc. & $54,182,000$ & $0.30 \%$ & $100.00 \%$ & 7.3 & $51.55 \%$ & $0.21 \%$ & $85.66 \%$ \\
\hline
\end{tabular}




\begin{tabular}{|c|c|c|c|c|c|c|c|c|}
\hline & & Size & Profitability & Tangibility & $\begin{array}{l}\text { Growth } \\
\text { opportunities }\end{array}$ & Tax & Volatility & $\begin{array}{l}\text { Capital } \\
\text { structure }\end{array}$ \\
\hline IMB & Imperial Brands Group & $27,634,000$ & $8.27 \%$ & $36.74 \%$ & 5.46 & $26.24 \%$ & $1.78 \%$ & $82.46 \%$ \\
\hline INF & Informa Plc. & $1,345,700$ & $3.99 \%$ & $10.62 \%$ & 2.59 & $2.69 \%$ & $3.15 \%$ & $56.34 \%$ \\
\hline IHG & $\begin{array}{l}\text { InterContinental Hotels } \\
\text { Group Plc. }\end{array}$ & $1,715,000$ & $23.71 \%$ & $55.86 \%$ & -4.51 & $29.44 \%$ & $10.69 \%$ & $125.93 \%$ \\
\hline IAG & $\begin{array}{l}\text { International Consolidated } \\
\text { Airlines Group SA }\end{array}$ & $22,567,000$ & $9.68 \%$ & $88.91 \%$ & 2.07 & $17.36 \%$ & $4.35 \%$ & $79.31 \%$ \\
\hline ITRK & Intertek Group Plc. & $2,567,000$ & $17.21 \%$ & $63.43 \%$ & 3.8 & $21.75 \%$ & $13.26 \%$ & $71.93 \%$ \\
\hline ITV & ITV Plc. & $3,075,000$ & $16.69 \%$ & $54.67 \%$ & 0.1093 & $18.28 \%$ & $3.88 \%$ & $78.93 \%$ \\
\hline JMAT & Johnson Matthey Plc. & $12,031,000$ & $10.57 \%$ & $80.82 \%$ & 11.56 & $16.68 \%$ & $1.12 \%$ & $52.50 \%$ \\
\hline KGF & Kingfisher & $11,225,000$ & $7.55 \%$ & $73.55 \%$ & 3.02 & $19.63 \%$ & $1.06 \%$ & $33.83 \%$ \\
\hline LAND & Land Securities Group Plc. & 787,000 & $3.51 \%$ & $99.76 \%$ & 14.56 & $0.89 \%$ & $6.38 \%$ & $22.42 \%$ \\
\hline LGEN & $\begin{array}{l}\text { Legal \& General Group } \\
\text { Plc. }\end{array}$ & $77,322,000$ & $0.09 \%$ & $100.00 \%$ & 1.21 & $32.24 \%$ & $0.01 \%$ & $96.28 \%$ \\
\hline LLOY & $\begin{array}{l}\text { Lloyds Banking Group } \\
\text { Plc. }\end{array}$ & $17,865,000$ & $2.18 \%$ & $100.00 \%$ & 0.6657 & $40.68 \%$ & $0.19 \%$ & $75.56 \%$ \\
\hline LSE & $\begin{array}{l}\text { London Stock Exchange } \\
\text { Group Plc. } \\
\end{array}$ & $2,285,400$ & $0.09 \%$ & $99.20 \%$ & 8.55 & $17.66 \%$ & $0.18 \%$ & $99.31 \%$ \\
\hline MKS & $\begin{array}{l}\text { Marks \& Spencer Group } \\
\text { Plc. }\end{array}$ & $10,622,000$ & $3.05 \%$ & $91.45 \%$ & 1.94 & $34.41 \%$ & $2.14 \%$ & $62.01 \%$ \\
\hline MDC & $\begin{array}{l}\text { Mediclinic International } \\
\text { Plc. }\end{array}$ & $2,749,000$ & $4.88 \%$ & $70.95 \%$ & 5.54 & $20.85 \%$ & $12.50 \%$ & $43.90 \%$ \\
\hline MERL & $\begin{array}{l}\text { Merlin Entertainments } \\
\text { Plc. }\end{array}$ & $1,457,000$ & $9.70 \%$ & $69.16 \%$ & 1.39 & $23.83 \%$ & $1.42 \%$ & $56.70 \%$ \\
\hline MCRO & $\begin{array}{l}\text { Micro Focus International } \\
\text { Plc. }\end{array}$ & $1,245,049$ & $6.35 \%$ & $26.60 \%$ & 5.46 & $16.59 \%$ & $9.53 \%$ & $65.62 \%$ \\
\hline MNDI & Mondi Plc. & $6,662,000$ & $12.90 \%$ & $89.04 \%$ & 8.74 & $18.62 \%$ & $2.29 \%$ & $49.44 \%$ \\
\hline MRW & \begin{tabular}{|l|} 
Morrison $(\mathrm{Wm})$ \\
Supermarkets \\
\end{tabular} & $16,317,000$ & $4.59 \%$ & $95.19 \%$ & 1.74 & $6.15 \%$ & $5.47 \%$ & $56.06 \%$ \\
\hline NG & National Grid & $16,922,000$ & $6.23 \%$ & $89.34 \%$ & 5.93 & $5.49 \%$ & $3.69 \%$ & $69.04 \%$ \\
\hline NXT & Next Plc. & $4,097,300$ & $35.87 \%$ & $98.20 \%$ & 3.47 & $19.60 \%$ & $0.94 \%$ & $78.77 \%$ \\
\hline OML & Old Mutual Plc. & $3,868,000$ & $0.71 \%$ & $98.56 \%$ & 1.63 & $64.10 \%$ & $0.06 \%$ & $93.49 \%$ \\
\hline PPB & Paddy Power Betfair Plc. & $1,500,800$ & $0.26 \%$ & $10.41 \%$ & 56.07 & $147.90 \%$ & $11.00 \%$ & $13.53 \%$ \\
\hline PSON & Pearson Plc. & $4,552,000$ & $-24.81 \%$ & $65.81 \%$ & 4.81 & $-8.68 \%$ & $11.86 \%$ & $56.81 \%$ \\
\hline PSN & Persimmon Plc. & $3,136,800$ & $18.59 \%$ & $94.85 \%$ & 8.87 & $19.30 \%$ & $3.89 \%$ & $33.95 \%$ \\
\hline PFG & Provident Financial Plc. & $1,643,000$ & $12.17 \%$ & $100.00 \%$ & 4.94 & $23.55 \%$ & $0.65 \%$ & $65.64 \%$ \\
\hline PRU & Prudential Plc. & $72,024,000$ & $0.35 \%$ & $100.00 \%$ & 5.97 & $12.48 \%$ & $0.15 \%$ & $92.82 \%$ \\
\hline RRS & Randgold Resources & $1,200,777$ & $10.00 \%$ & $100.00 \%$ & 29.56 & $26.92 \%$ & $4.14 \%$ & $7.15 \%$ \\
\hline RB & $\begin{array}{l}\text { Reckitt Benckiser Group } \\
\text { Plc. }\end{array}$ & $9,891,000$ & $13.37 \%$ & $25.33 \%$ & 11.7 & $23.31 \%$ & $4.26 \%$ & $53.24 \%$ \\
\hline REL & RELX Plc. & $6,895,000$ & $12.82 \%$ & $24.97 \%$ & 0.9339 & $20.64 \%$ & $17.46 \%$ & $82.30 \%$ \\
\hline RTO & Rentokil Initial Plc. & $2,168,100$ & $9.14 \%$ & $60.69 \%$ & 0.4539 & $19.52 \%$ & $4.73 \%$ & $85.81 \%$ \\
\hline RIO & Rio Tinto Plc. & $33,781,000$ & $7.05 \%$ & $96.06 \%$ & 18.34 & $24.70 \%$ & $3.73 \%$ & $48.77 \%$ \\
\hline RR & Rolls Royce Holdings Plc. & $14,955,000$ & $0.16 \%$ & $80.11 \%$ & 1.76 & $13.03 \%$ & $11.18 \%$ & $92.70 \%$ \\
\hline RBS & $\begin{array}{l}\text { Royal Bank of Scotland } \\
\text { Group Plc. }\end{array}$ & $12,720,000$ & $1.59 \%$ & $100.00 \%$ & 4.14 & $28.56 \%$ & $0.25 \%$ & $90.74 \%$ \\
\hline RDSA & $\begin{array}{l}\text { Royal Dutch Shell Plc. A } \\
\text { Shares } \\
\end{array}$ & $233,591,000$ & $1.88 \%$ & $94.17 \%$ & 20.02 & $14.79 \%$ & $2.87 \%$ & $54.16 \%$ \\
\hline RDSB & $\begin{array}{l}\text { Royal Dutch Shell Plc. B } \\
\text { Shares }\end{array}$ & $233,591,000$ & $1.36 \%$ & $94.17 \%$ & 20.02 & $17.35 \%$ & $2.02 \%$ & $54.16 \%$ \\
\hline RMG & Royal Mail Plc. & $9,776,000$ & $2.60 \%$ & $89.40 \%$ & 5 & $18.51 \%$ & $1.04 \%$ & $40.03 \%$ \\
\hline RSA & RSA Insurance Group & $7,220,000$ & $0.48 \%$ & $96.56 \%$ & 3.86 & $114.89 \%$ & $1.11 \%$ & $81.80 \%$ \\
\hline
\end{tabular}




\begin{tabular}{|c|c|c|c|c|c|c|c|c|}
\hline & & Size & Profitability & Tangibility & $\begin{array}{l}\text { Growth } \\
\text { opportunities }\end{array}$ & Tax & Volatility & $\begin{array}{l}\text { Capital } \\
\text { structure }\end{array}$ \\
\hline SGE & Sage Group Plc. & $1,569,100$ & $10.33 \%$ & $33.45 \%$ & 1.04 & $32.23 \%$ & $3.29 \%$ & $60.35 \%$ \\
\hline SBRY & Sainsbury (J) Plc. & $26,224,000$ & $3.38 \%$ & $96.24 \%$ & 3.14 & $25.05 \%$ & $2.42 \%$ & $65.18 \%$ \\
\hline SDR & Schroders Plc. & $1,789,700$ & $2.95 \%$ & $0.00 \%$ & 9.44 & $20.69 \%$ & $0.16 \%$ & $19.32 \%$ \\
\hline SMT & $\begin{array}{l}\text { Scottish Mortgage } \\
\text { Investment Trust }\end{array}$ & $(10,744)$ & $-0.35 \%$ & $100.00 \%$ & 3.59 & $-6.16 \%$ & $15.21 \%$ & $12.54 \%$ \\
\hline SGRO & Segro Plc. & 225,500 & $3.83 \%$ & $99.95 \%$ & 5.06 & $1.81 \%$ & $6.76 \%$ & $31.56 \%$ \\
\hline SVT & Severn Trent Plc & $1,885,200$ & $6.03 \%$ & $98.21 \%$ & 3.85 & $2.03 \%$ & $1.49 \%$ & $89.78 \%$ \\
\hline SHP & Shire Plc. & $11,396,600$ & $1.40 \%$ & $21.56 \%$ & 26.8 & $25.94 \%$ & $11.32 \%$ & $56.82 \%$ \\
\hline SKY & Sky Plc. & $11,965,000$ & $5.53 \%$ & $47.39 \%$ & 2.23 & $11.84 \%$ & $5.65 \%$ & $80.24 \%$ \\
\hline SN & Smith \& Nephew Plc. & $4,669,000$ & $15.35 \%$ & $50.99 \%$ & 3.73 & $26.18 \%$ & $3.13 \%$ & $46.11 \%$ \\
\hline SMIN & Smiths Group Plc. & $2,949,000$ & $8.70 \%$ & $61.06 \%$ & 4.6 & $24.57 \%$ & $1.33 \%$ & $62.89 \%$ \\
\hline SKG & Smurfit Kappa Group Plc. & $8,159,000$ & $9.19 \%$ & $72.04 \%$ & 9.89 & $29.97 \%$ & $1.26 \%$ & $71.76 \%$ \\
\hline SSE & SSE Plc. & $29,037,900$ & $8.11 \%$ & $96.82 \%$ & 6.18 & $3.25 \%$ & $2.18 \%$ & $73.77 \%$ \\
\hline STJ & St. James's Place Plc & $9,156,700$ & $0.19 \%$ & $100.00 \%$ & 1.96 & $25.87 \%$ & $0.13 \%$ & $97.25 \%$ \\
\hline STAN & Standard Chartered Plc. & $14,023,000$ & $2.17 \%$ & $100.00 \%$ & 12.06 & $146.70 \%$ & $0.47 \%$ & $87.66 \%$ \\
\hline SLA & $\begin{array}{l}\text { Standard Life Aberdeen } \\
\text { Plc. }\end{array}$ & $18,712,000$ & $0.36 \%$ & $100.00 \%$ & 2.21 & $13.96 \%$ & $0.15 \%$ & $84.98 \%$ \\
\hline TW & Taylor Wimpey Plc. & $3,676,200$ & $16.24 \%$ & $99.93 \%$ & 0.849 & $19.59 \%$ & $2.52 \%$ & $38.88 \%$ \\
\hline TSCO & Tesco Plc. & $56,460,000$ & $2.14 \%$ & $94.07 \%$ & 0.7875 & $263.64 \%$ & $5.75 \%$ & $86.01 \%$ \\
\hline TUI & TUI AG & $17,184,600$ & $4.97 \%$ & $76.49 \%$ & 3.15 & $24.81 \%$ & $2.91 \%$ & $77.53 \%$ \\
\hline ULVR & Unilever Plc. & $52,713,000$ & $13.82 \%$ & $51.38 \%$ & 5.2 & $25.73 \%$ & $0.73 \%$ & $69.91 \%$ \\
\hline UU & United Utilities Group Plc. & $1,704,000$ & $4.87 \%$ & $98.49 \%$ & 4.14 & $1.92 \%$ & $1.83 \%$ & $77.29 \%$ \\
\hline VOD & Vodafone Group Plc. & $53,458,000$ & $-0.88 \%$ & $70.12 \%$ & 2.47 & $165.69 \%$ & $20.96 \%$ & $52.34 \%$ \\
\hline WTB & Whitbread Plc. & $3,106,000$ & $11.11 \%$ & $94.12 \%$ & 13.79 & $19.31 \%$ & $0.52 \%$ & $46.15 \%$ \\
\hline WPG & Worldpay Group Plc. & $4,540,800$ & $4.21 \%$ & $67.23 \%$ & 0.4446 & $50.21 \%$ & $2.46 \%$ & $87.32 \%$ \\
\hline WPP & WPP Plc. & $14,388,900$ & $6.17 \%$ & $55.36 \%$ & 7.28 & $20.57 \%$ & 0.0044 & $71.74 \%$ \\
\hline
\end{tabular}

Appendix B: OLS Estimation (With Five Explanatory Variables—SIZE, ROA, TANG, PB, and TAX)

Dependent Variable: TL

Method: Least Squares

Sample: 1,101

Included observations: 101

\begin{tabular}{lllll}
\hline Variable & Coefficient & Std. Error & T-statistic & Prob. \\
\hline C & 0.775727 & 0.071849 & 10.79666 & 0.0000 \\
SIZE & $7.21 \mathrm{E}-10$ & $5.19 \mathrm{E}-10$ & 1.389409 & 0.1680 \\
ROA & -0.194291 & 0.283943 & -0.684261 & 0.4955 \\
TANG & -0.065088 & 0.078578 & -0.828318 & 0.4096 \\
PB & -0.014940 & 0.002606 & -5.733528 & 0.0000 \\
TAX & 0.021943 & 0.031914 & 0.687567 & 0.4934 \\
\hline R-squared & 0.264570 & Mean dependent var & 0.639787 \\
Adjusted R-squared & 0.225864 & S.D. dependent var & \\
S.E. of regression & 0.196682 & Akaike info criterion & & -0.356359 \\
Sum squared resid & 3.674947 & Schwarz criterion & -0.201539 \\
Log likelihood & 24.02310 & Hannan-Quinn criter & -0.294001 \\
F-statistic & 6.835238 & Durbin-Watson stat & & 1.744978 \\
Prob. (F-statistic) & 0.000017 & & \\
\hline
\end{tabular}


Appendix C: OLS Estimation (With Six Explanatory Variables-SIZE, ROA, TANG, PB, TAX, and Volatility)

Dependent Variable: TL

Method: Least Squares

Sample: 1,101

Included observations: 101

\begin{tabular}{|c|c|c|c|c|}
\hline Variable & Coefficient & Std. Error & T-statistic & Prob. \\
\hline $\mathrm{C}$ & 0.839252 & 0.078842 & 10.64475 & 0.0000 \\
\hline SIZE & $6.62 \mathrm{E}-10$ & $5.13 \mathrm{E}-10$ & 1.290280 & 0.2001 \\
\hline ROA & -0.256070 & 0.282387 & -0.906802 & 0.3668 \\
\hline TANG & -0.100348 & 0.079910 & -1.255769 & 0.2123 \\
\hline $\mathrm{PB}$ & -0.014742 & 0.002575 & -5.724078 & 0.0000 \\
\hline TAX & 0.027286 & 0.031648 & 0.862180 & 0.3908 \\
\hline VOLTY & -0.939964 & 0.508667 & -1.847897 & 0.0678 \\
\hline R-squared & 0.290350 & \multicolumn{2}{|c|}{ Mean dependent var } & 0.639787 \\
\hline Adjusted R-squared & 0.245053 & \multicolumn{2}{|c|}{ S.D. dependent var } & 0.223540 \\
\hline S.E. of regression & 0.194229 & \multicolumn{2}{|c|}{ Akaike info criterion } & -0.372774 \\
\hline Sum squared resid & 3.546127 & \multicolumn{2}{|c|}{ Schwarz criterion } & -0.191528 \\
\hline Log likelihood & 25.82507 & \multicolumn{2}{|c|}{ Hannan-Quinn criter. } & -0.299400 \\
\hline F-statistic & 6.409935 & \multicolumn{2}{|c|}{ Durbin-Watson stat } & 1.762751 \\
\hline Prob. (F-statistic) & 0.000011 & & & \\
\hline
\end{tabular}

Appendix D: OLS Estimation (With Six Explanatory Variables—SIZE, ROA, TANG, PB, TAX, and Volatility and Four Dummy Industry Classification Variables)

Dependent Variable: TL

Method: Least Squares

Sample: 1,101

Included observations: 101

\begin{tabular}{lllll}
\hline Variable & Coefficient & Std. Error & T-statistic & Prob. \\
\hline C & 0.803622 & 0.086137 & 9.329556 & 0.0000 \\
SIZE & $5.54 \mathrm{E}-10$ & $5.98 \mathrm{E}-10$ & 0.927336 & 0.3562 \\
ROA & -0.205483 & 0.292523 & -0.702452 & 0.4842 \\
PB & -0.013707 & 0.002608 & -5.256604 & 0.0000 \\
TANG & -0.057879 & 0.086674 & -0.667778 & 0.5060 \\
TAX & 0.052724 & 0.034321 & 1.536217 & 0.1280 \\
VOLTY & -0.831098 & 0.518103 & -1.604116 & 0.1122 \\
D1 & 0.026596 & 0.083960 & 0.316774 & 0.7521 \\
D2 & -0.046922 & 0.080795 & -0.580755 & 0.5629 \\
D3 & -0.018865 & 0.056406 & -0.334450 & 0.7388 \\
D4 & -0.189611 & 0.084622 & -2.240686 & 0.0275 \\
\hline R-squared & 0.332098 & Mean dependent var & & 0.639787 \\
Adjusted R-squared & 0.257887 & S.D. dependent var & & 0.223540 \\
S.E. of regression & 0.192571 & Akaike info criterion & & -0.354197 \\
Sum squared resid & 3.337509 & Schwarz criterion & & -0.069382 \\
Log likelihood & 28.88694 & Hannan-Quinn criter. & & -0.238896 \\
F-statistic & 4.475035 & Durbin-Watson stat & & 1.698556 \\
Prob. (F-statistic) & 0.000040 & & & \\
\hline
\end{tabular}

